\title{
6. NEOGENE SUBSIDENCE ALONG THE NORTHEASTERN AUSTRALIAN MARGIN: BENTHIC FORAMINIFERAL EVIDENCE ${ }^{1}$
}

\author{
Miriam E. Katz ${ }^{2}$ and Kenneth G. Miller ${ }^{3}$
}

\begin{abstract}
We use benthic foraminifers to reconstruct the Neogene paleobathymetric history of the Marion Plateau, Queensland Plateau, Townsville Trough, and Queensland Trough on the northeastern Australian margin (Ocean Drilling Program Leg 133). Western Queensland Plateau Site 811/825 (present depth, $938 \mathrm{~m})$ deepened from the neritic zone $(0-200 \mathrm{~m})$ to the upper bathyal zone (200-600 m) during the middle Miocene ( 13-14 Ma), with further deepening into the middle bathyal zone $(600-1000 \mathrm{~m})$ occurring during the late Miocene ( $7 \mathrm{Ma})$. A depth transect across the southern Queensland Plateau shows that deepening from the outer neritic zone $(100-200 \mathrm{~m})$ to the upper bathyal zone began during the latest Miocene $(\sim 6 \mathrm{Ma})$ at the deepest location (Site 813, present depth, $539.1 \mathrm{~m}$ ), whereas the shallower Sites 812 and 814 (present depths, 461.6 and $520.4 \mathrm{~m}$, respectively) deepened during the late Pliocene ( 2.7 and 2.9 Ma). At Marion Plateau Site 815 (present depth, $465.5 \mathrm{~m}$ ), water depth increased during the late Miocene ( $6.7 \mathrm{Ma})$ from the outer neritic to the upper bathyal zone. Nearby Site 816 (present water depth, 437.3 $\mathrm{m}$ ) contains Pliocene upper bathyal assemblages that directly overlie middle Miocene shallow neritic deposits; the timing of the deepening is uncertain because of a late Miocene hiatus. On the northern slope of the Townsville Trough (Site 817, present depth, $1015.8 \mathrm{~m})$, benthic foraminifers and sponge spicules indicate deepening from the lower upper bathyal $(400-600 \mathrm{~m})$ to the middle bathyal zone in the late Miocene (by $\sim 6.8 \mathrm{Ma}$ ). Benthic foraminiferal faunas at nearby Site 818 (present water depth, $752.1 \mathrm{~m}$ ) do not show evidence of paleobathymetric change; however, a late Pliocene ( 2-3 Ma) increase in downslope transport may have been related to the drowning of the Queensland Plateau. Site 822 (present depth, $955.2 \mathrm{~m}$ ), at the base of the Great Barrier Reef slope, deepened from the upper bathyal to the middle bathyal zone during the late Pliocene (by $\sim 2.3 \mathrm{Ma}$ ). Queensland Trough Site 823 (present depth, $1638.4 \mathrm{~m}$ ) deepened from the middle bathyal to the lower bathyal $(1000-2000 \mathrm{~m})$ zone during the late Miocene ( $\sim 6.5 \mathrm{Ma})$. Benthic foraminiferal faunal changes at these Leg 133 sites indicate that rapid deepening occurred during the middle Miocene ( 13-14 Ma), late Miocene (6-7 Ma), and late Pliocene (2-3 Ma) along the northeastern Australian margin.
\end{abstract}

\section{INTRODUCTION}

One of the objectives of Leg 133 was to determine the paleobathymetric histories of the Marion and Queensland plateaus. Sixteen sites were drilled during Leg 133 (Fig. 1), including a seven-site transect that extends across the Townsville Trough from the Queensland Plateau in the north to the Marion Plateau in the south (Fig. 2), and a three-site transect across the Queensland Trough from the western Queensland Plateau to the Australian continental margin (Fig. 3). These sites range from 437 to $1638 \mathrm{~m}$ (present depth) and provide an opportunity to study Neogene paleobathymetric changes along the northeastern Australian margin.

Benthic foraminiferal faunas have long been recognized for their utility in estimating paleodepths (e.g., Natland, 1933; Bandy, 1960). Recent efforts have improved paleobathymetric resolution primarily for deep-sea (>200 m) calcareous (van Morkhoven et al., 1986) and agglutinated forms (Kaminski, 1988). Van Morkhoven et al. (1986) synthesized information about paleobathymetrically and biostratigraphically useful Cenozoic deep-water benthic foraminifers and also used published studies to establish paleobathymetric distributions of selected neritic benthic foraminifers. Although their database began with Gulf of Mexico studies, they expanded their investigations to include a global compilation of stratigraphic and paleobathymetric distributions of cosmopolitan deep-water benthic foraminifers. Many of these were used during Leg 133 drilling to estimate paleobathymetric changes on the northeastern Australian margin (Davies, McKenzie, Palmer-Julson, et al., 1991).

Early efforts (e.g., Natland, 1933) recognized that paleobathymetric estimates can be complicated by the downslope transport of

\footnotetext{
${ }^{1}$ McKenzie, J.A., Davies, P.J., Palmer-Julson, A., et al., 1993. Proc. ODP, Sci. Results, 133: College Station, TX (Ocean Drilling Program).

${ }^{2}$ Lamont-Doherty Earth Observatory, Palisades, NY 10964, U.S.A.

${ }^{3}$ Department of Geological Sciences, Rutgers University, New Brunswick, NJ 08903, and Lamont-Doherty Earth Observatory, Palisades, NY 10964, U.S.A.
}

shallower-water specimens. Downslope transport of shallow-water (predominantly reefal and off-reef) taxa was observed at every site during Leg 133, which hampered paleobathymetric interpretations. Katz and Miller (in press) isolated transported elements from in-situ faunas in environments similar to those of Leg 133. They distinguished the dominant in-situ benthic foraminiferal assemblages from the transported reefal elements in the Miocene-Pliocene Jamaican Buff Bay section using quantitative techniques. We use this information to identify transported benthic foraminiferal faunal elements in the Leg 133 assemblages and to interpret qualitatively in-situ faunas for paleobathymetric fluctuations.

We base our paleobathymetric estimates on the presence/absence of key indicator taxa, relying on the concept that benthic foraminifers have upper and lower depth limits (Bandy, 1960). Streeter (1973) and Schnitker (1974) established that deep-water (bathyal-abyssal; $>200$ m) benthic foraminifers are correlated to watermass properties that may vary independently of depth (see also Lohmann, 1978; Corliss, 1979; Schnitker, 1979; Murray, 1984). Subsequent studies have documented that deep-water benthic foraminiferal distributions also are associated with other physicochemical properties that may vary independently of depth and watermass (e.g., carbonate availability, Bremer and Lohmann, 1982; grain size, Miller and Lohmann, 1982; organic carbon content, Lutze, 1978; surface-water productivity, Gooday, 1988; oxygen concentration, Schnitker, 1979). Because of temporal variations in watermass and other physicochemical properties, benthic foraminiferal abundance biofacies have migrated through depth and time (e.g., Douglas and Woodruff, 1981; Tjalsma and Lohmann, 1983; Kurihara and Kennett, 1988), as the depth preferences of individual taxa have changed through time (van Morkhoven et al., 1986).

Van Morkhoven et al. (1986) evaluated these changes in paleobathymetric ranges of biofacies and individual taxa by relying on published and unpublished age-distributional data (e.g., Tjalsma and Lohmann, 1983; Miller and Katz, 1987). They established that many taxa previously thought to be isobathyal (with constant upper or lower depth limits through time; Bandy, 1960) may have changed paleo- 


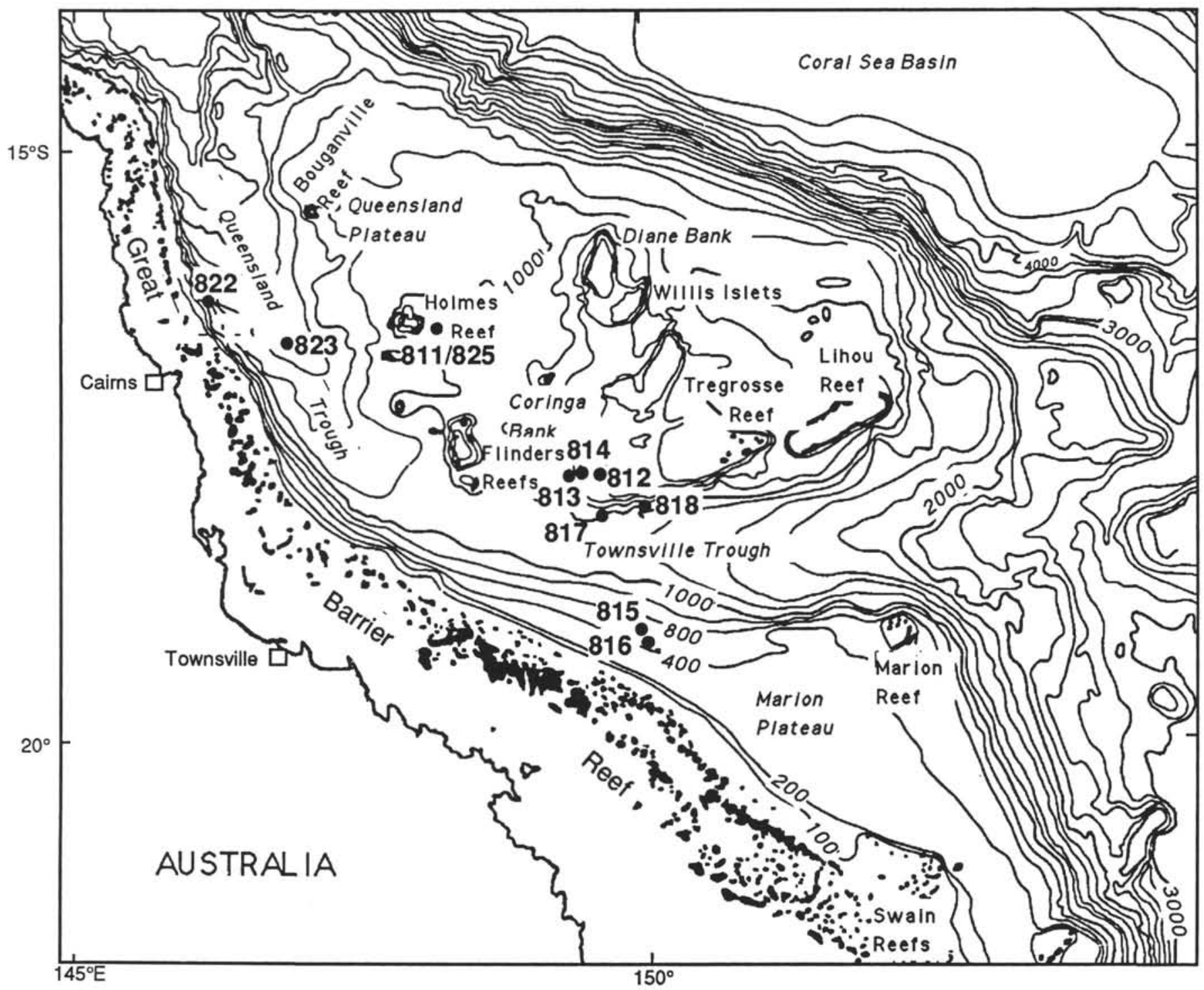

Figure 1. Location map showing Leg 133 sites used in this study (after Davies, McKenzie, Palmer-Julson, et al., 1991). Bathymetry in meters.

depth preferences through time. Van Morkhoven et al. (1986) have provided the most comprehensive synthesis of changes in depth preferences, and we used their upper and lower depth limits in our paleobathymetric estimates. Van Marle (1989) used depth ranges published in van Morkhoven et al. (1986) to determine the paleobathymetry of two middle Pliocene-Pleistocene sections from eastern Indonesia. He confirmed these paleodepth estimates by correlating them to the upper depth limits of Holocene eastern Indonesian benthic foraminifers (van Marle, 1988). We think that these studies show that the van Morkhoven et al. (1986) depth zonations can be used to estimate paleobathymetry in the southwestern Pacific region.

Many of our paleobathymetric estimates rely on the upper/lower depth limits of only a few taxa (and in some cases, only one). We base our estimates on local, rather than global, first and last occurrences; local changes may result from either oceanographic or bathymetric changes. We postulate that the benthic foraminiferal changes observed in the Leg 133 boreholes resulted primarily from paleobathymetric changes because consistent faunal successions occur at boreholes in different tectonic and oceanographic settings. Physical barriers prevent similar oceanographic conditions from existing at all sites at the same time; therefore, we interpret coeval benthic foraminiferal successions in different oceanographic regimes on the northeastern Australian margin as reflecting synchronous bathymetric changes.

Preliminary shipboard studies of benthic foraminifers from corecatcher samples revealed evidence for paleobathymetric change during the middle Miocene, late Miocene, and late Pliocene along the northeastern Australian margin. More detailed sampling at these locations has allowed us to refine the timing of Miocene and Pliocene subsidence history of the Marion Plateau, Queensland Plateau, Queensland Trough, and Townsville Trough.

\section{METHODS}

Samples examined for benthic foraminiferal content were soaked in a sodium metaphosphate solution, washed through a $63-\mu \mathrm{m}$ sieve, and oven-dried. Benthic foraminifers were quantitatively picked from aliquots of the greater than $150-\mu \mathrm{m}$ size fraction and mounted on reference slides. In general, at least 300 specimens were selected per sample. Qualitative benthic foraminiferal data, including shipboard core-catcher samples, are incorporated in our study.

Interpretation of Leg 133 paleobathymetric changes is complicated by the downslope transport of shallower-water taxa. We quali- 


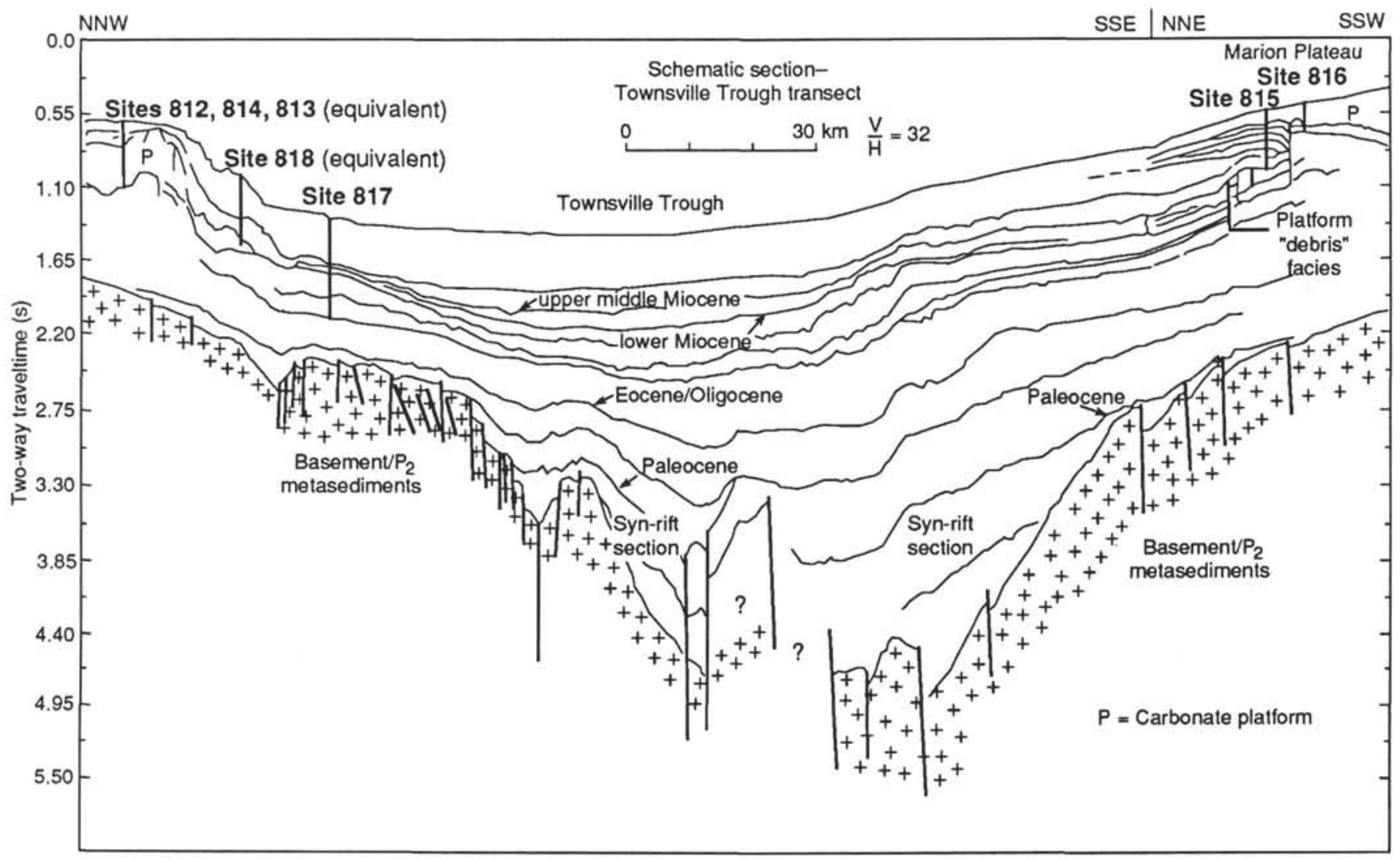

Figure 2. Cross section showing the bathymetric relationships of the Townsville Trough transect sites (after Davies, McKenzie, Palmer-Julson, et al., 1991).

tatively differentiated transported reefal and shallow neritic elements (e.g., Asterigerina, Amphistegina, Planorbulina, Discorbis, and Planodiscorbis) from in-situ benthic foraminifers. Identifications of in-situ, depth-diagnostic benthic foraminiferal species are drawn from the taxonomic base of van Morkhoven et al. (1986). Paleobathymetric estimates are primarily based on presence/absence of key benthic foraminiferal taxa. In addition, quantitative analyses (fluctuating percentages of certain depth-diagnostic species) were calculated for several sites, but these species percentages showed no recognizable trends.

We follow the bathymetric zonation terminology of van Morkhoven et al. (1986) and Berggren and Miller (1989). The neritic zone $(0-200 \mathrm{~m})$ is divided into three subzones: inner $(0-30 \mathrm{~m})$, middle $(30-100 \mathrm{~m})$, and outer $(100-200 \mathrm{~m})$. The bathyal zone $(200-2000 \mathrm{~m})$ also is divided into three subzones: upper $(200-600 \mathrm{~m})$, middle (600-1000 m), and lower (1000-2000 m). Because these depth ranges are relatively broad, a bathymetric change that occurs within a depth zone may not be reflected in the benthic foraminiferal assemblages.

Age models for each site were developed primarily based on nannofossil datums (Gartner and Wei, this volume; Wei and Gartner, this volume) because of their high sampling resolution. Planktonic foraminifer datums (Davies, McKenzie, Palmer-Julson, et al., 1991) generally agree with the nannofossil datums within the margin of error introduced by the larger sample spacing (Table 1). Radiolarian age estimates were used for part of the Miocene section at Site 817 (Davies, McKenzie, Palmer-Julson, et al., 1991). Larger benthic foraminifer age estimates were used for Miocene sections at several sites (Davies, McKenzie, Palmer-Julson, et al., 1991). Age estimates for samples examined for benthic foraminifers were determined by interpolating between datums and extrapolating where necessary. Numerical estimates of datums follow those used by Gartner and Wei (this volume) and Wei and Gartner (this volume); for comparison, the numerical age estimates of Berggren et al. (1985) are provided (Table 1).

\section{RESULTS}

We present benthic foraminiferal ranges and paleobathymetric estimates within a chronostratigraphic framework for each of the 10 sites plotted vs. depth (Figs. 4-13) and summarize the paleobathymetric changes through time by physiographic region (Fig. 14).

\section{Site 811/825}

Western Queensland Plateau Site 825 (939.4 m, present depth) is a reoccupation of Site 811 (937 m, present depth); these two sites are combined here (Figs. 1, 3). The lower part of the section examined (268.27-347.35 mbsf; 13.8-17.9 Ma based on a long age extrapolation) contains bioclastic skeletal sands, gravels, and hard-grounds; it lacks the bathyal taxa that were found in overlying samples and contains shallow-water (various cibicidids and uvigerinids) and reefal elements (e.g., Asterigerina, Amphistegina, and Planorbulina), indicating neritic depths $(0-200 \mathrm{~m})$ for this interval (Fig. 4). A middle Miocene water depth increase (between 264.60 and $268.27 \mathrm{mbsf}$; 13-14 Ma; this age is uncertain, see below) into the upper bathyal zone $(200-600 \mathrm{~m})$ is indicated by the first occurrences of Cibicidoides mundulus, Rectuvigerina striata, and Hanzawaia mantaensis and by the lack of deeper-water indicators (Fig. 4). The first occurrences of Anomalinoides globulosus, Planulina wuellerstorfi, and Cibicidoides robertsonianus (Samples $811 \mathrm{~A}-15 \mathrm{H}-2,50-54 \mathrm{~cm}$, and $-14 \mathrm{H}-\mathrm{CC}$ ) indicate that further deepening occurred during the late Miocene (between 131.00 and $138.50 \mathrm{mbsf} ; 7.0$ and $7.3 \mathrm{Ma}$ ) from upper bathyal to middle bathyal depths $(600-1000 \mathrm{~m})$ (Fig. 4). The timing of this paleobathymetric change was calculated by interpolating across a long interval from the highest occurrence of Discoaster quinqueramus (91.6 mbsf, 5.26 Ma; Wei and Gartner, this volume) to the highest occurrence of Discoaster hamatus (172.6 
Table 1. Biostratigraphic datums used to establish age models for the Leg 133 sites.

\begin{tabular}{|c|c|c|c|c|c|c|c|c|c|c|c|}
\hline Datum & $\begin{array}{l}\text { Age } \\
(\mathrm{Ma})^{a}\end{array}$ & $811 \mathrm{~A} / 825$ & $\begin{array}{l}812 \mathrm{~A}, \\
812 \mathrm{C}\end{array}$ & $813 \mathrm{~A}$ & $814 \mathrm{~A}$ & $815 \mathrm{~A}$ & $816 \mathrm{~A}$ & $817 \mathrm{~A}$ & $818 \mathrm{~B}$ & $822 \mathrm{~A}$ & $\begin{array}{l}823 \mathrm{~B} \\
823 \mathrm{C}\end{array}$ \\
\hline FO E. huxleyi & $0.275 / 0.275$ & & 2.67 & 2.63 & 4.12 & 1.1 & & 25.07 & 9.53 & & 12.20 \\
\hline LO $P$. lacunosa & $0.465 / 0.474$ & 8.90 & 7.52 & 9.83 & 10.01 & 4.1 & & 28.07 & 14.03 & $\begin{array}{l}21.80 \\
54.80\end{array}$ & 32.00 \\
\hline FO G. spp.C-D & $\begin{array}{l}0.81^{\mathrm{b}} \\
0.92^{\mathrm{b}}\end{array}$ & & & & & & & & & 77.80 & 80.2 \\
\hline Small Geph. Acme top & $0.93^{b}$ & & 17.02 & 23.82 & 21.01 & 13.9 & 4.87 & 45.56 & 53.51 & & \\
\hline $\begin{array}{l}\text { Small Geph. Acme bottom } \\
\text { LO G. spp. A-B }\end{array}$ & $\begin{array}{l}1.1^{\mathrm{b}} \mathrm{b} \\
1.10^{\mathrm{b}}\end{array}$ & & & & & 17.4 & & 51.56 & & 125,60 & 95.50 \\
\hline LOH. sellii & $1.27 / 1.37$ & & & & & 18.9 & & & & 220.00 & 105.70 \\
\hline LO C. macinyrei & $1.48 / 1.45$ & & & 33.32 & & 20.4 & 9.62 & 63.06 & 80.51 & 301.50 & 150.90 \\
\hline LO D. brouweri & $1.88 / 1.9$ & 22.90 & & 39.81 & 33.51 & 24.9 & 12.62 & 72.56 & & 333.40 & 163.00 \\
\hline LO D. pentaradiatus & $2.29 / 2.4$ & 29.40 & 23.00 & & 41.51 & & & & & 399.30 & 222.30 \\
\hline LO D. surculus & $2.42 / 2.4$ & & & 53.81 & 44.51 & 36.4 & 17.62 & & 106.01 & 411.00 & 236.20 \\
\hline LO D. tamalis & $2.6 / 2.6$ & 38.90 & & 57.31 & 53.40 & 44.72 & 19.12 & 75.56 & 177.02 & 419.00 & 244.30 \\
\hline LOS abies & $3.45 / 3.47$ & & & 79.31 & 66.83 & & & 155.70 & 246.08 & & \\
\hline LO R. pseudoumbilica & $3.51 / 3.5$ & 72.60 & 58.00 & 80.81 & & 158.90 & 76.11 & & 259.51 & & 359.30 \\
\hline $\begin{array}{l}\text { FO D. assymetricus } \\
\text { FO P. lacunosa }\end{array}$ & $\begin{array}{l}3.88 / 4.0 \\
4.0 / 3.4\end{array}$ & & & & & 309.46 & & 161.06 & & & 435.50 \\
\hline LO A.triconiculatus & $4.24 / 3.7$ & 76.90 & & & & & & & & & 521.60 \\
\hline LO C. armatus & $4.6^{\mathrm{b}^{\prime 2}}$ & & & & & 326.35 & & & & & 602.00 \\
\hline $\begin{array}{l}\text { FO C. rugosus } \\
\text { FOC, armatus }\end{array}$ & $\begin{array}{l}4.72 / 4.5 \\
5.06^{6}\end{array}$ & & & & & & & 176.70 & & & \\
\hline $\begin{array}{l}\text { FOC. armatus } \\
\text { LOD. quinqueranus }\end{array}$ & $\begin{array}{l}5.06 \\
5.26 / 5.6\end{array}$ & 91.60 & 85.61 & 99.81 & 76.0 & $\begin{array}{l}351.0 \\
354.0\end{array}$ & & 180.07 & & & 653.00 \\
\hline LO A. amplificus & $5.6 / 5.6$ & & & & & 378.54 & & 186.07 & & & 733.10 \\
\hline FO A. amplificus & $5.9 / 5.9$ & & & & & 387.3 & & 195.57 & & & 767.60 \\
\hline FO A. primusidelicatus & $6.74 / 6.5$ & & & & & 409.36 & & 200.56 & & & \\
\hline FO D. quinqueramus & $8.2 / 8.2$ & & & & & & & & & & 967.40 \\
\hline LO C calyculus & $8.75 / 8.75$ & & & & & & & & & & 971.90 \\
\hline LO D. hamatus & $8.85 / 8.85$ & 172.60 & & & & & & & & & \\
\hline LOC. coalitus & $9.0 / 9.0$ & & & & & & & & & & 989.80 \\
\hline middle Miocene ${ }^{\mathrm{c}}$ & 10.4 & & & 196.29 & & & & & & & \\
\hline FO C. coalitus & $10.8 / 10.8$ & & & & & & & & & & 1009.10 \\
\hline LO C. floridamus & $11.0 / 11.6$ & 214.30 & & & & & & & & & \\
\hline Radiolarians $\mathrm{c}^{\mathrm{c}} \mathrm{c}$ & 11.5 & & & & & & & 234.00 & & & \\
\hline $\begin{array}{l}\text { LO S. heteromorphus }{ }^{\mathrm{c}} \\
\text { Radiolarians } \mathrm{s}^{\mathrm{c}}\end{array}$ & $13.6^{\mathrm{d}}$ & & & & 114.0 & & & & & & \\
\hline $\begin{array}{l}\text { Radiolarians } \mathrm{c}^{\mathrm{c}} \\
\text { latest early to }\end{array}$ & $\begin{array}{l}15.3 \\
16.6\end{array}$ & & & & & 454.4 & & 301.60 & & & \\
\hline $\begin{array}{l}\text { early middle Miocene } \\
\text { within range of } \\
\text { S. heterom. }\end{array}$ & $\leq 17.1$ & & & & 241.76 & & & & & & \\
\hline
\end{tabular}

Note: $\mathrm{LO}=$ last occurrence; $\mathrm{FO}=$ first occurrence.

${ }^{\mathrm{a}}$ Gartner and Wei or Wei and Gartner (this volume)/Berggren et al. (1985).

Datum not included in Berggren et al. (1985).

cDatum from Davies, McKenzie, Palmer-Julson, et al. (1991).

Backman et al. (1990).

mbsf, $8.85 \mathrm{Ma}$; Wei and Gartner, this volume). Given the uncertainty in this interpolation, we propose that this deepening at Site 811/825 represents the same late Miocene deepening observed at other Leg 133 sites ( 6-7 Ma; see below).

\section{Site 812}

Site 812 was drilled at $461.6 \mathrm{~m}$ on the Queensland Plateau (Figs. 1, 2). Benthic foraminifers could not be extracted below Core 133-812A16X. Sections in and below Core 133-812A-18X reflect lagoonal to back-reef environments (Davies, McKenzie, Palmer-Julson, et al., 1991). Samples were examined for benthic foraminifers from the upper Miocene through the Pleistocene sections. The occurrences of Cibicidoides matanzasensis and Sphaeroidina bulloides in Sample 133$812 \mathrm{~A}-10 \mathrm{X}-\mathrm{CC}$ and the absence of deeper-water indicators found in overlying samples indicate middle neritic depths (30-100 m) (Fig. 5). A deepening to the outer neritic zone $(100-200 \mathrm{~m})$ during the late Pliocene is indicated by the first occurrences of Cibicidoides dutemplei and $C$. subhaidingerii in Sample 133-812C-5H-4, 75-80 cm (34.75 mbsf, 2.7 Ma). A few specimens of Hanzawaia mantaensis in Sample $133-812 \mathrm{C}-5 \mathrm{H}-2,75-80 \mathrm{~cm}(31.75 \mathrm{mbsf}, 2.6 \mathrm{Ma})$ mark the transition from outer neritic to upper bathyal benthic foraminiferal assemblages (Fig. 5). Although Hanzawaia mantaensis is generally found from 200 to $1000 \mathrm{~m}$, rare specimens have been reported in outer neritic deposits (van Morkhoven et al., 1986). The first occurrence of Cibicidoides mundulus in Sample 133-812A-4H-CC (26.40 mbsf, 2.4 Ma) marks deepening into the upper bathyal zone $(200-600 \mathrm{~m})$ in the uppermost Pliocene section. The presence of Bulimina marginata places a lower depth limit of $600 \mathrm{~m}$ on the section (Fig. 5).

\section{Site 813}

Site 813 is located on the Queensland Plateau at $539.1 \mathrm{~m}$, present depth (Figs. 1,2). Larger benthic foraminifers reflect depths of 0 to $50 \mathrm{~m}$ from Samples 133-813A-24V-CC through -22X-CC (middle to lower upper Miocene), while changes in these faunas indicate that Cores 133-813A-21X through -18H (lower upper Miocene) were deposited at water depths of about 50 to $200 \mathrm{~m}$ (Davies, McKenzie, Palmer-Julson, et al., 1991; Fig. 6). Above this, the first occurrence of S. bulloides in Sample 133-813A-15H-CC (138.70 mbsf, 7.3 Ma) reflects an upper depth limit of $30 \mathrm{~m}$; the absence of the deeper water indicators found higher in the section indicates middle neritic depths (30-100 m; Fig. 6). The change in larger benthic foraminiferal faunas, coupled with the smaller benthic foraminiferal depth estimate, indicates that a deepening from the inner $(0-30 \mathrm{~m})$ to the middle $(30-100$ $\mathrm{m})$ neritic zone occurred during the middle to early late Miocene. Faunas indicate that this site remained within the middle neritic zone until the late Miocene (116.95 mbsf, 6.2 Ma). Further deepening to the outer neritic zone $(100-200 \mathrm{~m})$ in the late Miocene is signaled by the first occurrence of Cibicidoides dutemplei in Sample 133-813A$8 \mathrm{H}$-CC (110.2 mbsf, 5.8 Ma; Fig. 6). Deepening continued into the upper bathyal realm $(200-600 \mathrm{~m})$, as indicated by the first occurrences of benthic foraminiferal species with upper depth limits of 200 $\mathrm{m}$ from 105.95 (5.6 Ma) to $77.41 \mathrm{mbsf}$ (3.4 Ma), including $C$. cicatricosus, H. mantaensis, Uvigerina proboscidea, and C. mundulus. At other locations, we used the first occurrence of $C$. mundulus to mark the upper bathyal zone. However, this species has a delayed first occurrence at Site 813 , appearing well above other upper bathyal markers. Therefore, we used the first occurrence of $C$. cicatricosus 


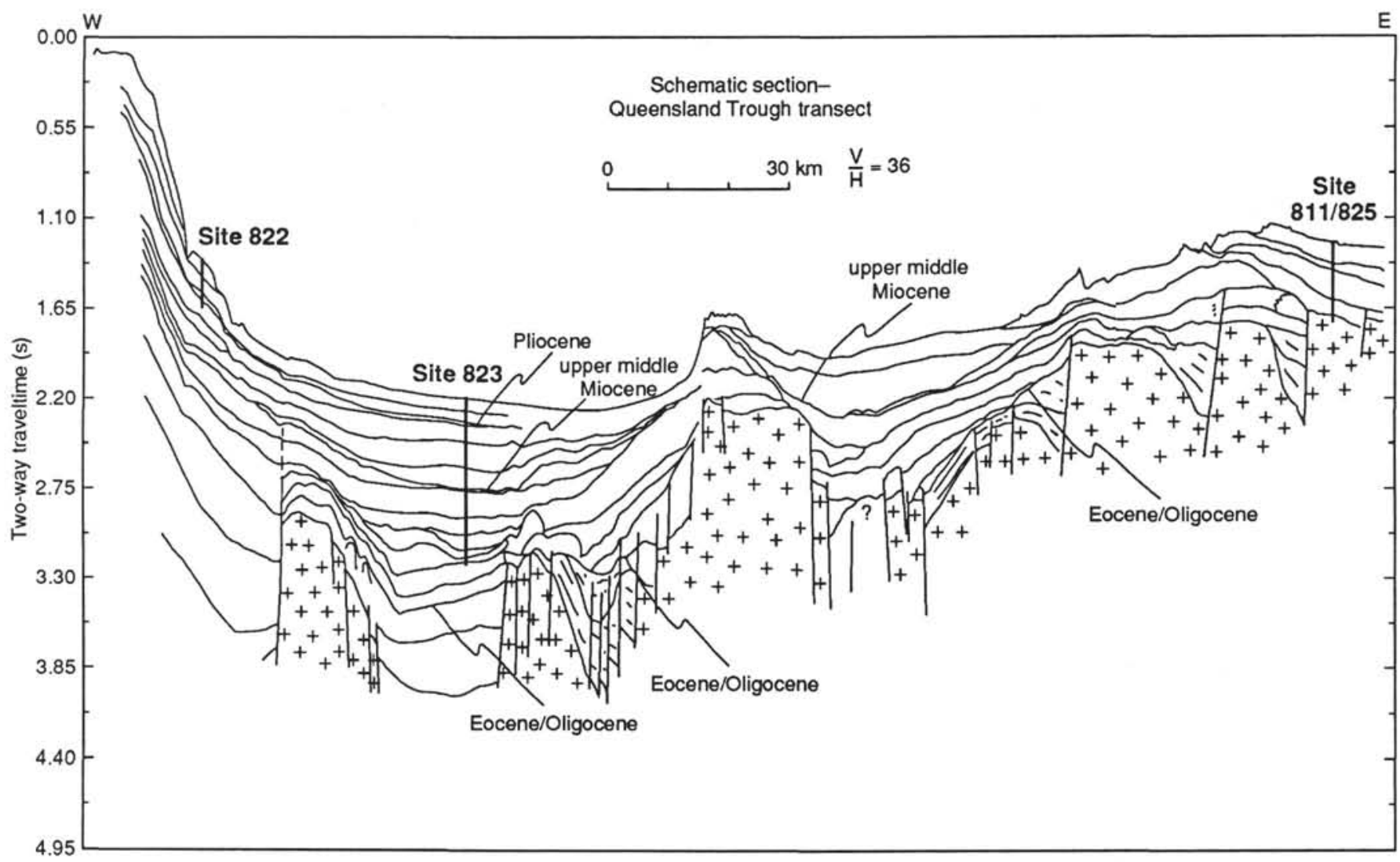

Figure 3. Cross section showing the bathymetric relationships of the Queensland Trough transect sites (after Davies, McKenzie, Palmer-Julson, et al., 1991).

(upper depth limit of $200 \mathrm{~m} ; 105.95 \mathrm{mbsf}, 5.6 \mathrm{Ma}$ ) to delineate the boundary between the outer neritic and upper bathyal zones at Site 813 (Fig. 6).

We estimate that a paleobathymetric change at Site 813 began during the late Miocene (between 6.2 and 5.8 Ma). The age model for Site 813 was developed by interpolating across a broad time interval from the highest occurrence of D. quinqueramus $(5.26 \mathrm{Ma})$ to an age estimate of middle Miocene based on larger benthic foraminifers (Davies, McKenzie, Palmer-Julson, et al,, 1991). We arbitrarily assigned the middle Miocene larger benthic foraminifer datum an age of $10.4 \mathrm{Ma}$, although this datum may actually be somewhat older. If the datum is older, then the timing of the subsidence at Site 813 would be slightly older. Despite the uncertainty in this interpolation, we think that the subsidence at Site 813 represents the same late Miocene event observed at other Leg 133 sites (ca. 6-7 Ma; see below).

\section{Site 814}

Site 814 was drilled at $520.4 \mathrm{~m}$ on the Queensland Plateau (Figs. 1, 2). The larger benthic foraminiferal Cycloclypeus and Nephrolepidina assemblage (Samples 133-814A-29X-CC to -9H-CC) reflects depths less than $30 \mathrm{~m}$ for much of the Miocene section at Hole $814 \mathrm{~A}$ (Davies, McKenzie, Palmer-Julson, et al., 1991). The co-occurrence of this assemblage with the first occurrence of $S$. bulloides (upper depth limit of $30 \mathrm{~m}$ ) in Sample 133-814A-9H-CC (76.00 mbsf, $5.3 \mathrm{Ma}$ ) indicates that either this sample was deposited in about $30 \mathrm{~m}$ of water or that the Cycloclypeus and Nephrolepidina assemblage was transported downslope and deposited slightly deeper in the middle neritic zone (30-100 m; Fig. 7). Pliocene Sample 133-814A-7H-CC (57.50 mbsf, $2.9 \mathrm{Ma})$ contains an outer neritic $(100-200 \mathrm{~m})$ benthic foraminiferal assemblage characterized by the first occurrence of Bulimina mexicana. The presence of $C$. mundulus in and above
Sample 133-814A-6H-CC (53.40 mbsf, 2.6 Ma) indicates deepening to upper bathyal depths (200-600 m) during the late Pliocene (Fig. 7).

\section{Site 815}

Site 815 is located on the Marion Plateau at the present depth of $465.5 \mathrm{~m}$ (Figs. 1,2). Benthic foraminiferal assemblages in and below Sample 133-815A-46X-CC (416.50 mbsf, 8.3 Ma) are dominated by reefal and shallow-water taxa (e.g., Amphistegina) and lack the depthdiagnostic species that are present in overlying samples; this part of the section can be assigned to inner to middle neritic depths ( $0-100$ m). Sample 133-815A-45X-CC (409.00 mbsf, 6.7 Ma) yielded an outer neritic fauna that included Bulimina mexicana, $C$. dutemplei, and rare $H$. mantaensis (Fig. 8). Samples 133-815A-45X-2, 75-80 $\mathrm{cm}$, and $-44 \mathrm{X}-2,73-78 \mathrm{~cm}$ ( 408.25 and $398.63 \mathrm{mbsf}, 6.7$ and $6.3 \mathrm{Ma}$, respectively) yield the first upper bathyal faunas $(200-600 \mathrm{~m})$, including Cibicidoides bradyi, C. cicatricosus, C. mundulus, C. subhaidingerii, $H$. mantaensis, Rectuvigerina striata, S. bulloides, Uvigerina carapitana, and $U$. proboscidea (Fig. 8).

\section{Site 816}

Site 816 was drilled on the Marion Plateau at $437.8 \mathrm{~m}$ (Figs. 1, 2). Benthic foraminifers could not be extracted from samples below lower Pliocene Sample 133-816A-10H-CC (91.00 mbsf, 3.8 Ma). Shipboard sedimentologists interpreted the floatstones, packstones, and rudstones below the unconformity at this level to indicate that middle Miocene environments were shallower than $5 \mathrm{~m}$ (Davies, McKenzie, Palmer-Julson, et al., 1991). The Pliocene-Pleistocene section in and above Sample 133-816A-10H-CC (91.00 mbsf, 3.8 Ma) contains upper bathyal $(200-600 \mathrm{~m})$ benthic foraminiferal assemblages that are characterized by the depth-indicative species $B$. 


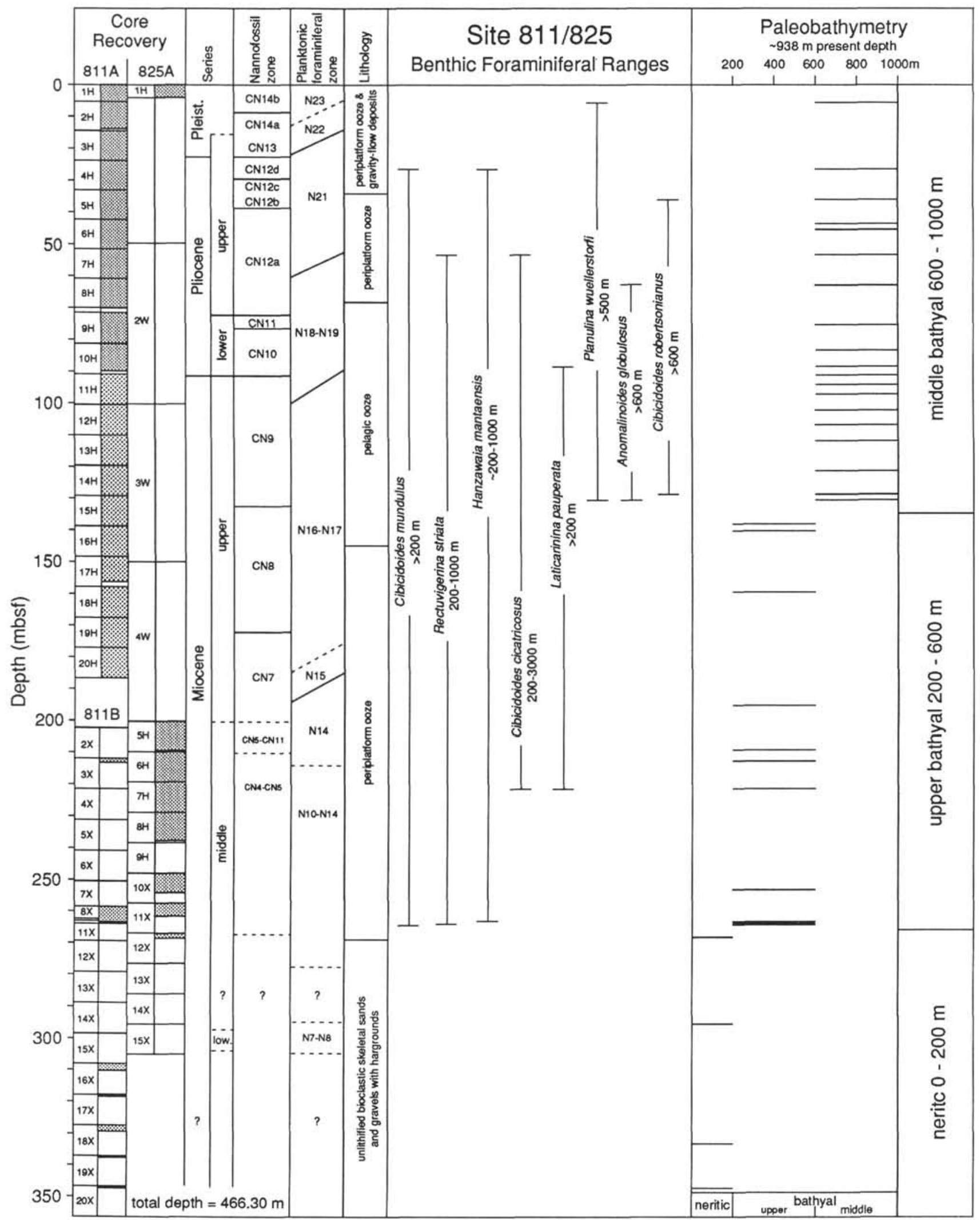

Figure 4. Combined Site $811 / 825$ benthic foraminiferal range data and paleobathymetric interpretation. The paleobathymetric interpretations of the benthic foraminiferal data are placed between samples examined. The following information applies to Figures 4-13: the first and last occurrences of benthic foraminifers are placed next to the sample level rather than between samples. Nannofossil zones are after Wei and Gartner (this volume). They place the Pliocene/Pleistocene boundary at the bottom of Zone CN13, whereas Berggren et al. (1985) placed it at the top of Zone CN13; both are shown here. Planktonic foraminiferal zones and generalized lithology are after Davies, McKenzie, Palmer-Julson, et al. (1991). The vertical lines represent the section over which a particular benthic foraminiferal species is present. Each of these range lines is accompanied by the species name and the depth range of that species. See text for complete species names. 


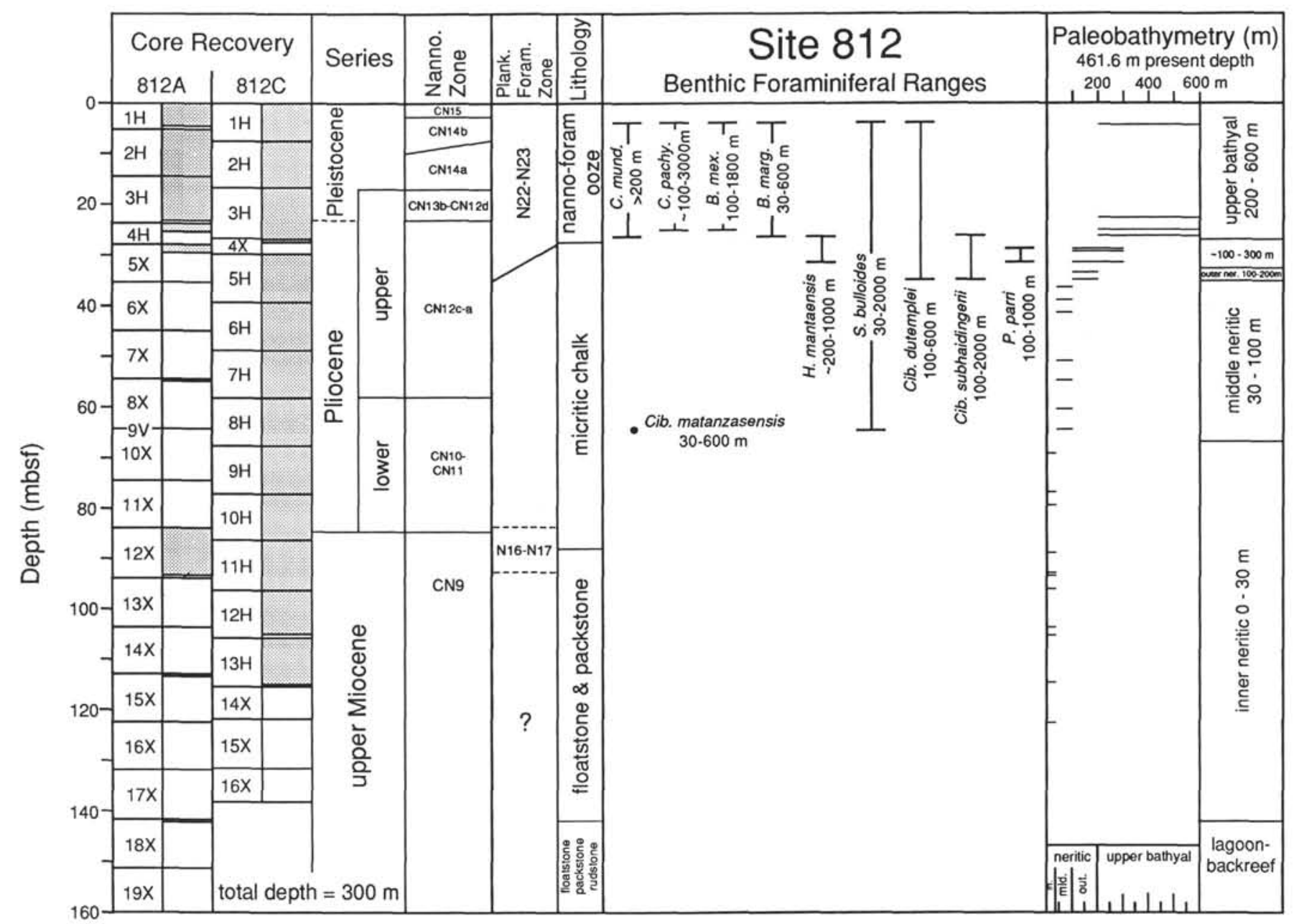

Figure 5. Site 812 benthic foraminiferal range data and paleobathymetric interpretation. The solid circle represents a species occurrence in a single sample. See Figure 4 caption for complete explanation.

marginata, B. mexicana, C. cicatricosus, C. dutemplei, C. mundulus, C. pachyderma, C. subhaidingerii, Planulina foveolata, S. bulloides, and Sigmoilopsis schlumbergeri (Fig. 9). Although it is clear that Site 816 subsided from shallower than $5 \mathrm{~m}$ to upper bathyal depths during the late Miocene, the hiatus at this time makes it impossible to constrain the exact timing of the paleobathymetric change.

\section{Site 817}

Site 817 is located in the Townsville Trough south of the Queensland Plateau at $1015.8 \mathrm{~m}$ (present depth; Figs. 1, 2). In-situ benthic foraminifers were examined in and above Sample 133-817A-29H-CC; recrystallization below this level hampered identifications. Poor core recovery in Hole $817 \mathrm{D}$ and a lower to middle middle Miocene baseof-slope debris apron (Davies, McKenzie, Palmer-Julson, et al., 1991) prevented paleobathymetric estimates deeper than about $300 \mathrm{mbsf}$. The middle Miocene section from Samples 133-817A-29H-CC, to $-22 \mathrm{H}-5$, 99-104 cm (269.80-202.69 mbsf, 13.5-7.0 Ma) contains upper bathyal $(200-600 \mathrm{~m})$ benthic foraminiferal faunas, including the depthindicative species $C$. dutemplei, $C$. guazumalensis, $C$. mundulus, $H$. mantaensis, and $R$. striata (Fig. 10). This paleobathymetric estimate can be further refined using sponge spicule assemblages. The sponge spicules indicate a depth greater than $400 \mathrm{~m}$ (Davies, McKenzie, Palmer-Julson, et al., 1991) in and above Sample 133-817A-33-CC; together with the benthic foraminiferal depth estimate, this indicates a paleodepth of 400 to $600 \mathrm{~m}$ for this part of the section (Fig. 10).
A late Miocene deepening to the middle bathyal zone (600-1000 m) occurred between 6.6 and $7.0 \mathrm{Ma}$ and is indicated by the first occurrences of A. globulosus (Sample 133-817A-22H-3, 99-104 cm), C. robertsonianus (Sample 133-817A-21H-2, 100-105 cm), Nuttallides umbonifera (Sample 133-817A-21H-2,100-105 cm), P. wuellerstorfi (Sample 133-817A-22H-3, 99-104 cm), and Pyrgo murrhina (Sample 133-817A-22H-5, 99-104 cm) (Fig. 10). The last occurrence of $H$. mantaensis in the upper Pliocene section reflects its global last appearance (van Morkhoven et al., 1986) and does not necessarily indicate a bathymetric change.

\section{Site 818}

An expanded Pliocene-Pleistocene section was recovered at Site 818 on the slope of the Queensland Plateau at $752.1 \mathrm{~m}$ (present depth; Figs. 1,2). All samples examined yielded middle bathyal (600-1000 $\mathrm{m}$ ) benthic foraminiferal faunas, including the depth indicators $C$. robertsonianus, $H$. mantaensis, $N$. umbonifera, Planulina rugosa, $P$. wuellerstorfi, and Pyrgo murrhina (Fig. 11). Samples 133-818B20H-CC through - $10 \mathrm{H}-\mathrm{CC}$ (188.90-93.90 mbsf, 2.8-2.0 Ma) contain abundant $B$. marginata, which has a lower depth limit of $600 \mathrm{~m}$, along with species that have upper depth limits of $600 \mathrm{~m}$ (Fig. 11). We speculate that the high abundances of this taxon may have resulted from increased downslope transport of displaced upper bathyal taxa in this part of the section, possibly as the result of the drowning of the adjacent Queensland Plateau (see below). Despite these possible 


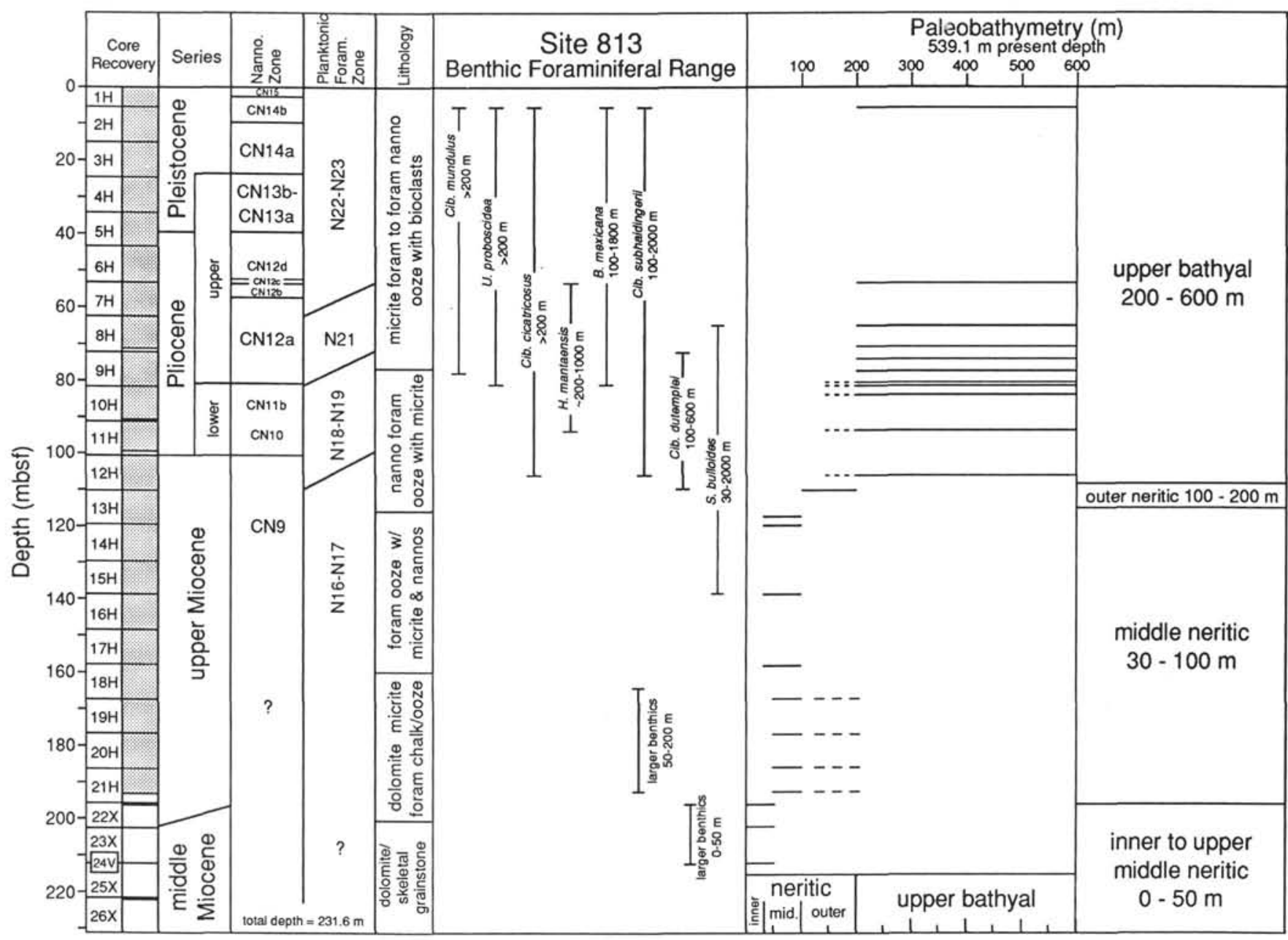

Figure 6. Site 813 benthic foraminiferal range data and paleobathymetric interpretation. Larger foraminiferal paleobathymetric depth estimates are after Davies, McKenzie, Palmer-Julson, et al. (1991). See Figure 4 caption for complete explanation.

transported elements, in-situ taxa indicate that the entire section at Hole $818 \mathrm{~B}$ was deposited in the middle bathyal zone $(600-1000 \mathrm{~m})$.

\section{Site 822}

Site 822 was drilled at $955.2 \mathrm{~m}$ (present depth) at the base of the Great Barrier Reef slope on the western flank of the Queensland Trough (Figs. 1,3). In-situ benthic foraminifers in and below Sample 133-822A-43X-CC (400.00 mbsf, $2.3 \mathrm{Ma})$ indicate upper bathyal (200-600 m) depths; in particular, C. dutemplei places a lower depth limit of $600 \mathrm{~m}$ on this part of the upper Pliocene section (Fig. 12). Planulina wuellerstorfi, which is generally found deeper than $500 \mathrm{~m}$ (M.E. Katz and K.G. Miller, unpubl. data), first appears in Sample 133-822A-42X-CC (394.44 mbsf, $2.3 \mathrm{Ma}$ ) and is consistently present above this level (Fig. 12). The last occurrence of $C$. dutemplei in Core 133-822A-43X and the first occurrence of Planulina wuellerstorfi in the overlying core indicate that there was an increase in water depth into the middle bathyal zone $(600-1000 \mathrm{~m})$ (Fig. 12) during the late Pliocene ( 2.3 Ma) at Site 822 .

\section{Site 823}

Site 823 is located in the central-western Queensland Trough at $1638.4 \mathrm{~m}$ present depth (Figs. 1, 3). Numerous (more than 1800) turbidites, debris flows, and slumps are interbedded with hemipelagic to pelagic sediments at this site (Davies, McKenzie, Palmer-Julson, et al., 1991). Many of the samples examined for benthic foraminiferal assemblages contain transported specimens (e.g., Amphistegina, Asterigerina, Planorbulina, and Discorbis) with otherwise in-situ species. Despite this mixing, we can estimate the bathymetric history of Site 823. In-situ benthic foraminiferal faunas in and below Sample 133-823C-10R-CC ( $879.86 \mathrm{mbsf}, 7.2 \mathrm{Ma})$ indicate that this part of the section was deposited at middle bathyal depths $(600-1000 \mathrm{~m})$. Species that provide a lower depth limit estimate of $1000 \mathrm{~m}$ include Plectofrondicularia parri, $P$. vaughani, and $H$. mantaensis. Pyrgo murrhina establishes an upper depth limit of $600 \mathrm{~m}$ for this part of the section (Fig. 13). In addition, a gravity deposit layer (Sample 133-812C-11R-2, 2-6 cm) yielded Anomalinoides globulosus, which also has an upper depth limit of $600 \mathrm{~m}$. Samples examined between Cores 133-823C-6R and -823B-84X (796.90-834.55 mbsf, 6.2-6.7 Ma) contained no depth-diagnostic in-situ benthic foraminifers. Samples in and above Core 133-823B-80X (767.00 mbsf, 5.9 $\mathrm{Ma}$ ) contain benthic foraminiferal assemblages that are typical of the middle to lower bathyal zones, although this part of the section generally lacks the species with lower depth limits of $1000 \mathrm{~m}$ that were found in the underlying samples. The exceptions to this are the occurrences of single specimens of $H$. mantaensis (lower depth limit of about $1000 \mathrm{~m}$ ) in Samples 133-823B-72X-CC and -61X-CC and $P$. parri in Sample 133-823B-61X-CC; these are probably the result of down-slope transport (Fig. 13). Therefore, deposition probably occurred within the lower bathyal zone (1000-2000 m) in and above Core 133-823B-80X (767.00 mbsf, 5.9 Ma). The benthic foraminiferal assemblage changes noted here reflect the late Miocene paleobathymetric change that occurred at Site 823 (between $~ 5.9$ and 7.2 


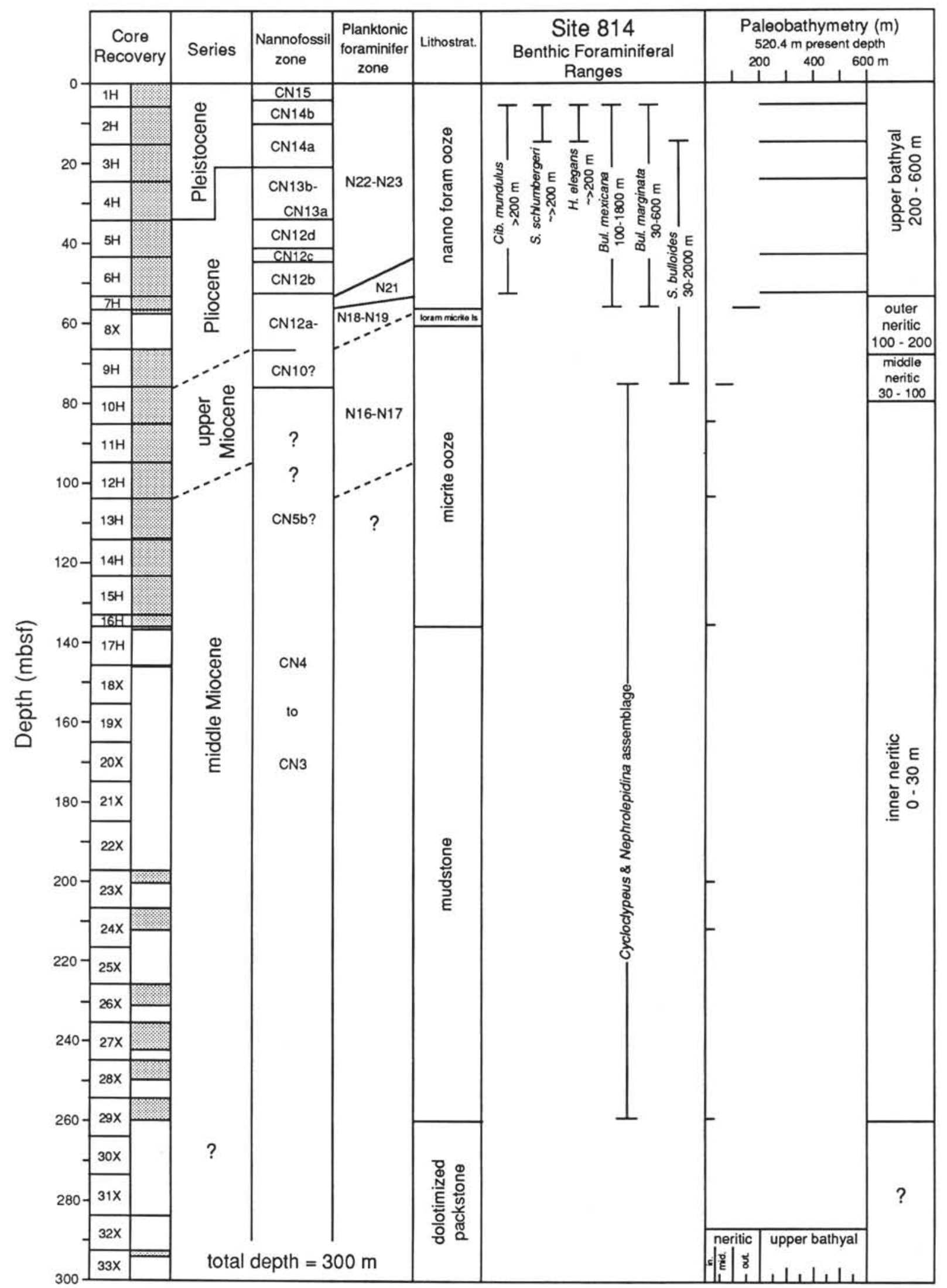

Figure 7. Site 814 benthic foraminiferal range data and paleobathymetric interpretation. Larger foraminiferal paleobathymetric depth estimates are after Davies, McKenzie, Palmer-Julson, et al. (1991). See Figure 4 caption for complete explanation. 


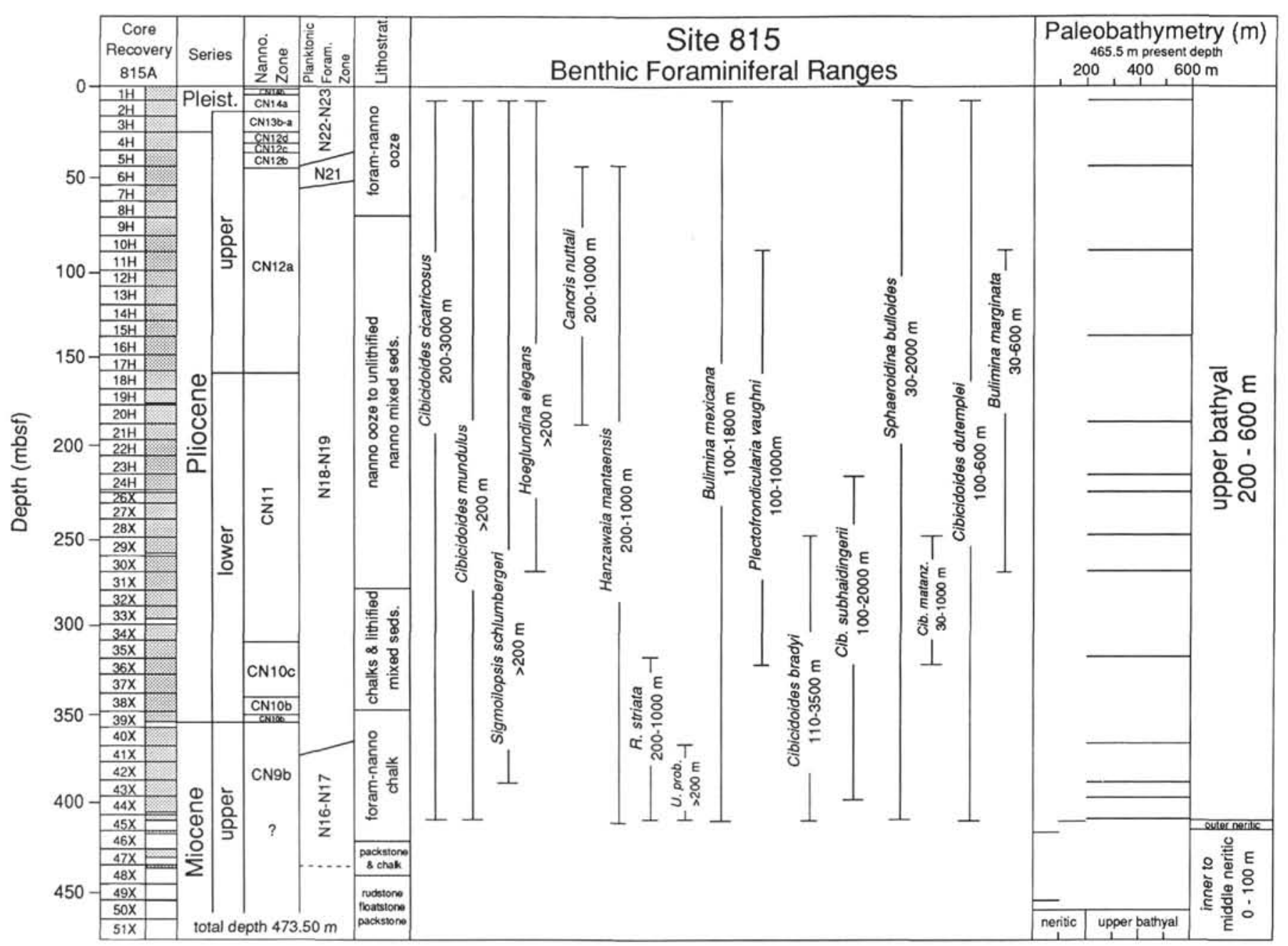

Figure 8 . Site 815 benthic foraminiferal range data and paleobathymetric interpretation. See Figure 4 caption for complete explanation.

Ma). A lower depth limit of $1800 \mathrm{~m}$ for Site 823 is indicated by Bulimina mexicana, Sigmoilopsis schlumbergeri, and Sphaeroidina bulloides (Fig. 13).

\section{DISCUSSION}

Changes in benthic foraminiferal faunas indicate that there were at least three periods of rapid water-depth increases along the northeastern Australian margin. These paleobathymetric changes occurred during the middle Miocene ( 13-14 Ma), the late Miocene (6-7 Ma), and the late Pliocene (2-3 Ma) (Fig. 14).

\section{Middle Miocene ( 13-14 Ma)}

At the western Queensland Plateau Site 811/825, there was a shift from neritic to upper bathyal faunas during the middle Miocene (between $264.60 \mathrm{mbsf}, \sim 13.6 \mathrm{Ma}$ and $268.27 \mathrm{mbsf}, \sim 13.8 \mathrm{Ma}$; Figs. 4, 14). The age estimate for this deepening is uncertain because it relies on extrapolation of sedimentation rates below $214 \mathrm{mbsf}$ (Table 1). It occurs near the base of a 50- to 60-m-thick section assigned to undifferentiated Zones CN4-CN5 (10.8-16.0 Ma; Wei and Gartner, this volume) and N10-N14 (10.4-14.9 Ma; Davies, McKenzie, Palmer-Julson, et al., 1991), and $\sim 30 \mathrm{~m}$ above a section assigned to undifferentiated Zones N7-N8 (15.2-17.6 Ma; Davies, McKenzie, Palmer-Julson, et al., 1991). These data are consistent with our rough estimate of 13 to $14 \mathrm{Ma}$ for the timing of this paleobathymetric change.
Site 817 is the only other site that contains sediment from this time interval; however, no change was observed in the benthic foraminiferal faunas at this level. This can be explained by one of the following:

1. Subsidence occurred within the upper bathyal zone at Site 817 and did not affect the assemblages. This would require differential subsidence between Sites 817 and $811 / 825$. The age models used place Site 817 at 400 to $600 \mathrm{~m}$ between 14 and $15 \mathrm{Ma}$ and Site $811 / 825$ at less than $200 \mathrm{~m}$ (Fig. 14); the present depth difference between the sites is only $78 \mathrm{~m}$.

2. The discrepancy is an artifact of uncertainties in correlation because of the extrapolation used in the Site 811/825 age model (see above). A minor difference in the age estimates could explain the apparent absence of subsidence at Site 817 and any apparent differential subsidence. This is the most plausible explanation.

3. Tectonic subsidence did not affect the entire plateau at this time. We cannot eliminate this as a possibility.

\section{Late Miocene (6-7 Ma)}

Several sites record late Miocene ( 6-7 Ma) increases in water depth along the northeastern Australian margin. Benthic foraminiferal faunas show that western Queensland Plateau Site 811/825 deepened from the upper bathyal zone ( $200-600 \mathrm{~m}$ ) to the middle bathyal zone $(600-1000 \mathrm{~m}$ ) during the late Miocene (between $131.00 \mathrm{mbsf}, \sim 7.0$ $\mathrm{Ma}$ and $138.50 \mathrm{mbsf}, \sim 7.3 \mathrm{Ma}$; Figs. 4,14 ). Benthic foraminiferal 
assemblage changes at Queensland Trough Site 823 reflect a late Miocene (between $767.00 \mathrm{mbsf}, \sim 5.9 \mathrm{Ma}$ and $879.86 \mathrm{mbsf}, \sim 7.2 \mathrm{Ma}$ ) deepening from the middle bathyal zone $(600-1000 \mathrm{~m})$ to the lower bathyal zone (1000-2000 m; Figs. 13, 14). Southern Queensland Plateau Site 813 deepened from the middle neritic zone to the upper bathyal zone during the late Miocene (between $116.95 \mathrm{mbsf}, \sim 6.2 \mathrm{Ma}$ and 105.95 mbsf, 5.6 Ma; Figs. 6, 14). Townsville Trough Site 817 benthic foraminiferal faunas also record a late Miocene (between $199.69 \mathrm{mbsf}, \sim 6.6 \mathrm{Ma}$ and $202.69 \mathrm{mbsf}, \sim 7.0 \mathrm{Ma}$ ) deepening from lower upper bathyal depths ( $400-600 \mathrm{~m}$ ) to the middle bathyal zone (600-1000 m; Figs. 10,14). Marion Plateau Site 815 contains benthic foraminiferal faunas that show a bathymetric change from the outer neritic zone (100-200 m) to the upper bathyal zone $(200-600 \mathrm{~m})$ in the late Miocene (between $408.25 \mathrm{mbsf}, \sim 6.70 \mathrm{Ma}$ and $409.00 \mathrm{mbsf}$, $\sim 6.73 \mathrm{Ma}$; Figs. 8, 14). At nearby Site 816 , Pliocene upper bathyal benthic foraminiferal faunas directly overlie middle Miocene sediments that were deposited in less than $5 \mathrm{~m}$ of water (Davies, McKenzie, Palmer-Julson, et al., 1991), indicating that a major deepening occurred between the middle Miocene and the Pliocene (Fig. 9). Although it is impossible to identify the exact timing of the bathymetric change at Site 816, a late Miocene deepening is consistent with the changes observed at other Leg 133 sites (Fig. 14).

\section{Late Pliocene (2-3 Ma)}

Benthic foraminiferal assemblages at Queensland Plateau Site 812 indicate that deepening from middle neritic depths $(30-100 \mathrm{~m})$ to outer neritic depths (100-200 m) began during the late Pliocene (between $36.25 \mathrm{mbsf}, \sim 2.8 \mathrm{Ma}$ and $34.75 \mathrm{mbsf}, \sim 2.7 \mathrm{Ma}$; Figs. 5, 14). This deepening continued at Site 812 to the upper bathyal zone (between $31.75 \mathrm{mbsf}, \sim 2.6 \mathrm{Ma}$ and $26.40 \mathrm{mbsf}, \sim 2.4 \mathrm{Ma}$; Figs. 5, 14). At nearby Site 814 , deepening from the middle to outer neritic zones occurred during the Pliocene (between $76.00 \mathrm{mbsf} ; 5.3 \mathrm{Ma}$ and $57.50 \mathrm{mbsf}$, $\sim 2.9 \mathrm{Ma}$; Figs. 7, 14). Site 814 continued to deepen to the upper bathyal zone during the late Pliocene (between $57.50 \mathrm{mbsf} \sim 2.9 \mathrm{Ma}$ and 53.40 mbsf, $\sim 2.6 \mathrm{Ma}$; Figs. 7, 14), at approximately the same time as the paleobathymetric change at Site 812. A coring gap and a limestone (that could not be processed for benthic foraminifers) between these levels make it impossible to constrain the timing of the beginning of the increase in water depth at Site 814, although it is clear that both Sites 812 and 814 were rapidly deepening at the same time. Nearby Site 813 was already within the upper bathyal zone during the late Pliocene, so that further deepening within this zone would not have been reflected in the benthic foraminiferal assemblages. Site 822 deepened from upper $(200-600 \mathrm{~m})$ to middle $(600-1000 \mathrm{~m})$ bathyal depths during the late Pliocene (between $400.00 \mathrm{mbsf}, \sim 2.3 \mathrm{Ma}$ and $394.44 \mathrm{mbsf}, \sim 2.26$ Ma; Figs. 12, 14). Site 818 is located on the southern flank of the Queensland Plateau near Sites 812 and 814 (Figs. 1, 2). Benthic foraminiferal faunas may contain shallower-water contaminants from 188.90 to $93.90 \mathrm{mbsf}(\sim 2.8-\sim 2.0 \mathrm{Ma})$ at Site 818 (Fig. 11); this interval coincides with the timing of the water depth changes at Sites 812 and 814. This increase in downslope transport may be related to the drowning of the Queensland Plateau that may have increased the amount of shallow-water material transported to the adjacent slope because carbonate platforms may shed material to the deep sea primarily during relative sea-level highstands (Droxler and Schlager, 1985).

\section{Regional Tectonic History}

Mid-Cretaceous to Paleocene extension and rifting (Taylor and Falvey, 1977) formed the Queensland-Townsville-Cato Trough rift basin system, separating the Queensland and Marion plateaus from the Australian continental shelf (Davies, McKenzie, Palmer-Julson, et al., 1991). Seafloor spreading began during the latest Cretaceous to the Paleocene and continued until the early Eocene (Symonds et al., 1983; Davies, McKenzie, Palmer-Julson, et al., 1991). Shortly after spreading ceased along the northeastern Australian margin, seafloor spreading began between the Australian and Antarctic plates (Falvey and Mutter, 1981). At the end of the Eocene, northeastern Australia was located between $29^{\circ}$ and $44^{\circ} \mathrm{S}$ (Davies, McKenzie, Palmer-Julson, et al., 1991). The northern margin of the Australian craton collided with a complex subduction system during the middle Oligocene (Pigram et al., 1989). By the end of the Oligocene, northeastern Australia was between $21^{\circ}$ and $36^{\circ} \mathrm{S}$ (Davies et al., 1987). Since then, this region has migrated nearly due north to its present location between $9^{\circ}$ and $24^{\circ} \mathrm{S}$ (Davies et al., 1987; Davies, McKenzie, Palmer-Julson, et al., 1991).

The benthic foraminiferal changes observed at the Leg 133 sites are consistent with the overall tectonic history, although the causes of the increases in water depth in the middle Miocene, late Miocene, and late Pliocene remain unresolved:

1. The Townsville and Queensland Troughs were in deep water (bathyal zone, $>200 \mathrm{~m}$ ) by the middle Miocene (Fig. 14), which is consistent with post-rift thermal subsidence.

2. The Marion and Queensland plateaus and the Great Barrier Reef slope remained shallow until the late Miocene (Fig. 14), as reef growth kept up with post-rift subsidence (Taylor and Falvey, 1977).

3. Sites on both the plateaus and in the troughs recorded two pulses of rapid subsidence, one in the late Miocene and one in the late Pliocene (Fig. 14). Minimum rates of increases in water depth can be calculated for sites with sufficient control. Late Miocene deepening occurred at the rate of at least $167 \mathrm{~m} / \mathrm{m} . y$. at Site 813 and $63 \mathrm{~m} / \mathrm{m} . \mathrm{y}$. at Site 815 . Late Pliocene rates were at least $250 \mathrm{~m} / \mathrm{m}$.y. at Site $812,120 \mathrm{~m} / \mathrm{m}$.y. at Site 814 , and $154 \mathrm{~m} / \mathrm{m} . \mathrm{y}$. at Site 822 . These rapid rates cannot be attributed solely to simple thermal subsidence or to Airy sediment loading; rapid tectonic subsidence (faulting or flexure) is required. The subsidence could have been caused by increased sediment input into the troughs that caused a downward flexing of the plateaus (G. Karner, pers. comm., 1992). Alternatively, these two intervals of rapid subsidence on the northeastern Australian margin may have resulted from the reactivation of older faults (P. Symonds, pers. comm., 1992). The cause of these deepenings remains unresolved.

4. Deep-water conditions were attained on the western flank of the Queensland Plateau by the middle Miocene ( 13-14 Ma; Site 811/825; Fig. 14). We have insufficient data to address the significance of the middle Miocene deepening observed at Site 811/825. However, the rapidity of the middle Miocene deepening from the inner neritic zone to the bathyal zone (Fig. 4) argues for an additional interval of rapid tectonic subsidence.

\section{SUMMARY}

Benthic foraminiferal assemblages indicate that there were at least two periods of rapid deepening in the northeastern Australian region during the late Miocene ( $6-7 \mathrm{Ma})$ and during the late Pliocene $(\sim 2-3$ $\mathrm{Ma})$. The late Miocene (6-7 Ma) increase in water depth is reflected in faunal changes at Queensland Plateau Sites 811/825 and 813, Queensland Trough Site 823, Townsville Trough Site 817, and Marion Plateau Sites 815 and 816 . The late Pliocene increase in water depth (2-3 Ma) is recorded in faunal changes at Queensland Plateau Sites 812 and 814 , Great Barrier Reef slope Site 822 , and possibly in Townsville Trough Site 818 . These intervals of rapid increases in water depth may be attributed to flexure resulting from sediment loading in the troughs or to faulting. A middle Miocene ( 13-14 Ma) change in benthic foraminiferal faunas at western Queensland Plateau Site 811/ 825 may also reflect a period of rapid water depth increase; however, the regional significance of this deepening remains unknown.

\section{ACKNOWLEDGMENTS}

We thank N. Christie-Blick, G. Karner, G. Mountain, and P. Symonds for helpful discussions and W.A. Berggren and D.K. Pak for reviews. A review by E. Thomas was particularly helpful. This 
project was supported by JOI/USSAC grant TAMREF P.O. 20515. This is Lamont-Doherty Earth Observatory Contribution No. 5054.

\section{REFERENCES}

Backman, J., Schneider, D.A., Rio, D., and Okada, H., 1990. Neogene lowlatitude magnetostratigraphy from Site 710 and revised age estimates of Miocene nannofossil datum events. In Duncan, R.A., Backman, J., Peterson, L.C., et al., Proc. ODP, Sci. Results, 115: College Station, TX (Ocean Drilling Program), 271-276.

Bandy, O.L., 1960. General correlation of foraminiferal structure with environment. Rep. 21st Int. Geol. Congr., Copenhagen, 22:7-19.

Berggren, W.A., Kent, D.V., and Van Couvering, J.A., 1985. The Neogene: Part 2. Neogene geochronology and chronostratigraphy. In Snelling, N.J. (Ed.), The Chronology of the Geological Record. Geol. Soc. London Mem., 10:211-260.

Berggren, W.A., and Miller, K.G., 1989. Cenozoic bathyal and abyssal calcareous benthic foraminiferal zonations. Micropaleontology, 35:308-320

Bremer, M.L., and Lohmann, G.P., 1982. Evidence for primary control of the distribution of certain Atlantic Ocean benthonic foraminifera by degree of carbonate saturation. Deep-Sea Res. Part A, 29:987-988.

Corliss, B.H., 1979. Recent deep-sea benthonic foraminiferal distributions in the southeast Indian Ocean: inferred bottom water routes and ecological implications. Mar. Geol., 31:115-138.

Davies, P.J., McKenzie, J.A., Palmer-Julson, A., et al., 1991. Proc. ODP, Init. Repts., 133: College Station, TX (Ocean Drilling Program).

Davies, P.J., Symonds, P.A., Feary, D.A., and Pigram, C.J., 1987. Horizontal plate motion: a key allocyclic factor in the evolution of the Great Barrier Reef. Science, 238:1697-1700.

Douglas, R.G., and Woodruff, F., 1981. Deep-sea benthic foraminifera. In Emiliani, C. (Ed.), The Sea (Vol. 7): New York (Wiley-Interscience), $1233-1327$.

Droxler, A.W., and Schlager, W., 1985. Glacial versus interglacial sedimentation rates and turbidite frequency in the Bahamas. Geology, 13:799-802.

Falvey, D.A., and Mutter, J.C., 1981. Regional plate tectonics and the evolution of Australia's passive continental margins. BMR J. Aust. Geol. Geophys., $6: 1-29$.

Gooday, A.J., 1988. A response by benthic foraminifera to the deposition of phytodetritus in the deep sea. Nature, 332:70-73.

Kaminski, M., 1988. Cenozoic deep-water agglutinated foraminifera in the North Atlantic [Ph.D. dissert]. Woods Hole Oceanographic Inst./Massachusetts Inst. of Technol.

Katz, M.E., and Miller, K.G., in press. Miocene-Pliocene bathyal benthic foraminifera and the uplift of Buff Bay, Jamaica. Mem.-Geol. Soc. Am.

Kurihara, K., and Kennett, J.P., 1988. Bathymetric migration of deep-sea benthic foraminifera in the southwest Pacific during the Neogene. $J$. Foraminiferal Res., 18:75-83.

Lohmann, G.P., 1978. Abyssal benthonic foraminifera as hydrographic indicators in the western South Atlantic Ocean. J. Foraminiferal Res., 8:6-34.
Lutze, G.F., 1978. Neogene benthonic foraminifera from Site 369, Leg 41 , Deep Sea Drilling Project. In Lancelot, Y., Seibold, E., et al., Init. Repts. DSDP, 41: Washington (U.S. Govt. Printing Office), 659-666.

Miller, K.G., and Katz, M.E., 1987. Oligocene to Miocene benthic foraminiferal and abyssal circulation changes in the North Atlantic. Micropaleontology, 33:97-149.

Miller, K.G., and Lohmann, G.P., 1982. Environmental distribution of Recent benthic foraminifera on the northeast United States continental slope. Geol. Soc. Am. Bull., 93:200-206.

Murray, J.W., 1984. Paleogene and Neogene benthic foraminifers from Rockall Plateau. In Roberts, D.G., Schnitker, D., et al., Init, Repts. DSDP, 81: Washington (U.S. Govt. Printing Office), 503-534.

Natland, M.L., 1933. The temperature and depth distribution of some Recent and fossil foraminifera in the southern California region. Scripps Inst. Oceanogr. Tech. Ser., 3:225-230.

Pigram, C.J., Davies, P.J., Feary, D.A., and Symonds, P.A., 1989. Tectonic controls on carbonate platform evolution in southern Papua New Guinea: passive margin to foreland basin. Geology, 17:199-202.

Schnitker, D., 1974. West Atlantic abyssal circulation during the past 120,000 years. Nature, 248:385-387.

, 1979. Cenozoic deep water benthic foraminifera, Bay of Biscay. In Montadert, L., Roberts, D.G., et al., Init. Repts. DSDP, 48: Washington (U.S. Govt. Printing Office), 377-413.

Streeter, S.S., 1973. Bottom water and benthonic foraminifera in the North Atlantic: glacial-interglacial contrasts. Quat. Res., 3:131-141.

Symonds, P.A., Davies, P.J., and Parisi, A., 1983. Structure and stratigraphy of the central Great Barrier Reef. BMR J. Aust. Geol. Geophys., 8:277-291.

Taylor, L., and Falvey, D.C., 1977. Queensland Plateau and Coral Sea Basin: stratigraphy, structure and tectonics. APEA J., 17:13-29.

Tjalsma, R.C., and Lohmann, G.P., 1983. Paleocene-Eocene bathyal and abyssal benthic foraminifera from the Atlantic Ocean. Micropaleontol. Spec. Publ., 4.

van Marle, L.J., 1988. Bathymetric distribution of benthic foraminifera on the Australian-Irian Jaya continental margin, eastern Indonesia. Mar. Micropaleontol., 13:97-152.

1989. Recent and fossil benthic foraminifera and late Cenozoic paleobathymetry of Seram, eastern Indonesia. Neth. J. Sea Res., 24:445-457. van Morkhoven, F.P.C.M., Berggren, W.A., and Edwards, A.S., et al., 1986. Cenozoic cosmopolitan deep-water benthic foraminifera. Bull. Cent. Rech. Explor-Prod. Elf-Aquitaine, Mem. 11.

Abbreviations for names of organizations and publication titles in ODP reference lists follow the style given in Chemical Abstracts Service Source Index (published by American Chemical Society).

\section{Ms 133SR-242}

Date of initial receipt: 2 April 1992

Date of acceptance: 13 October 1992 


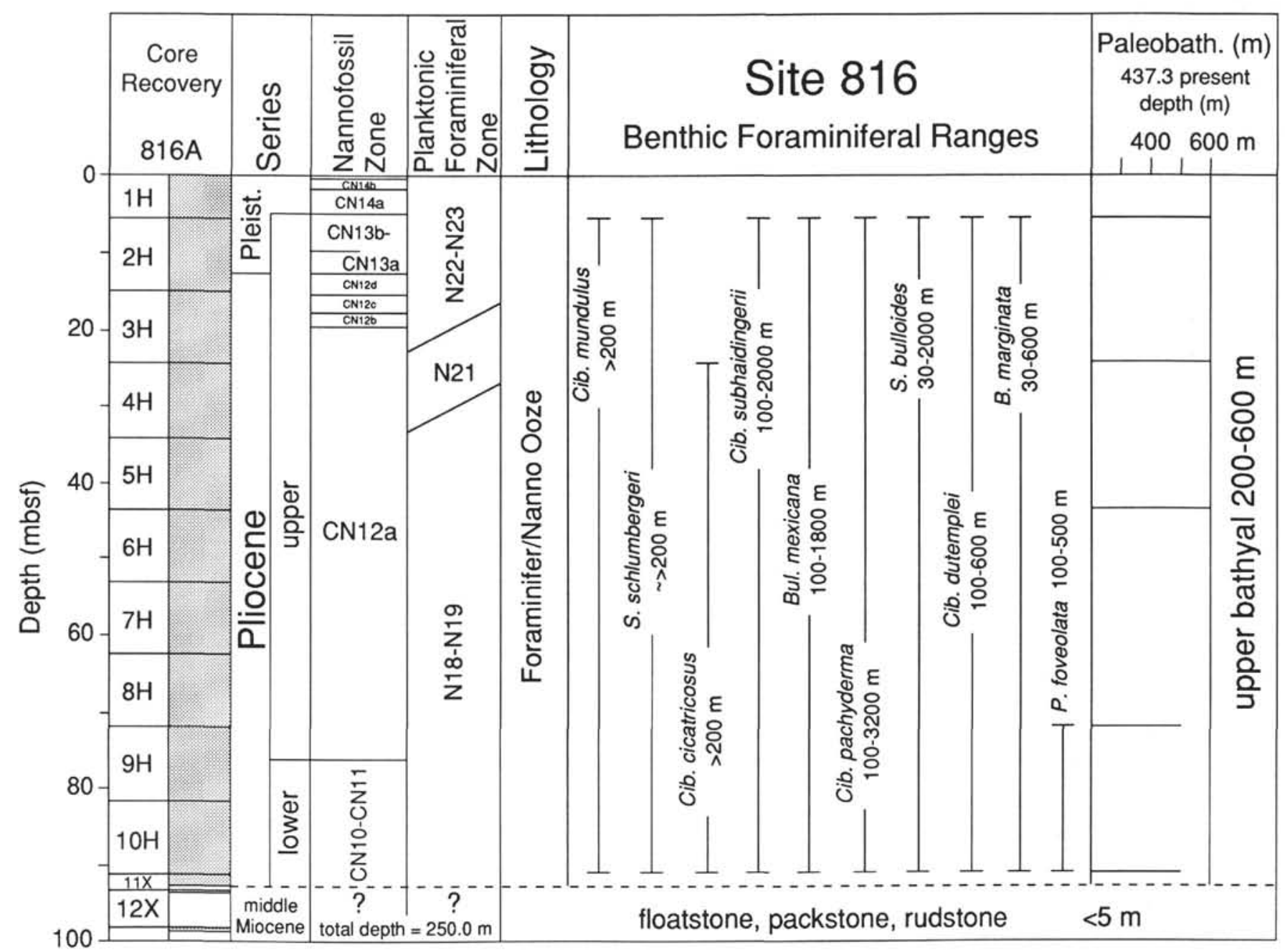

Figure 9. Site 816 benthic foraminiferal range data and paleobathymetric interpretation. See Figure 4 caption for complete explanation. 


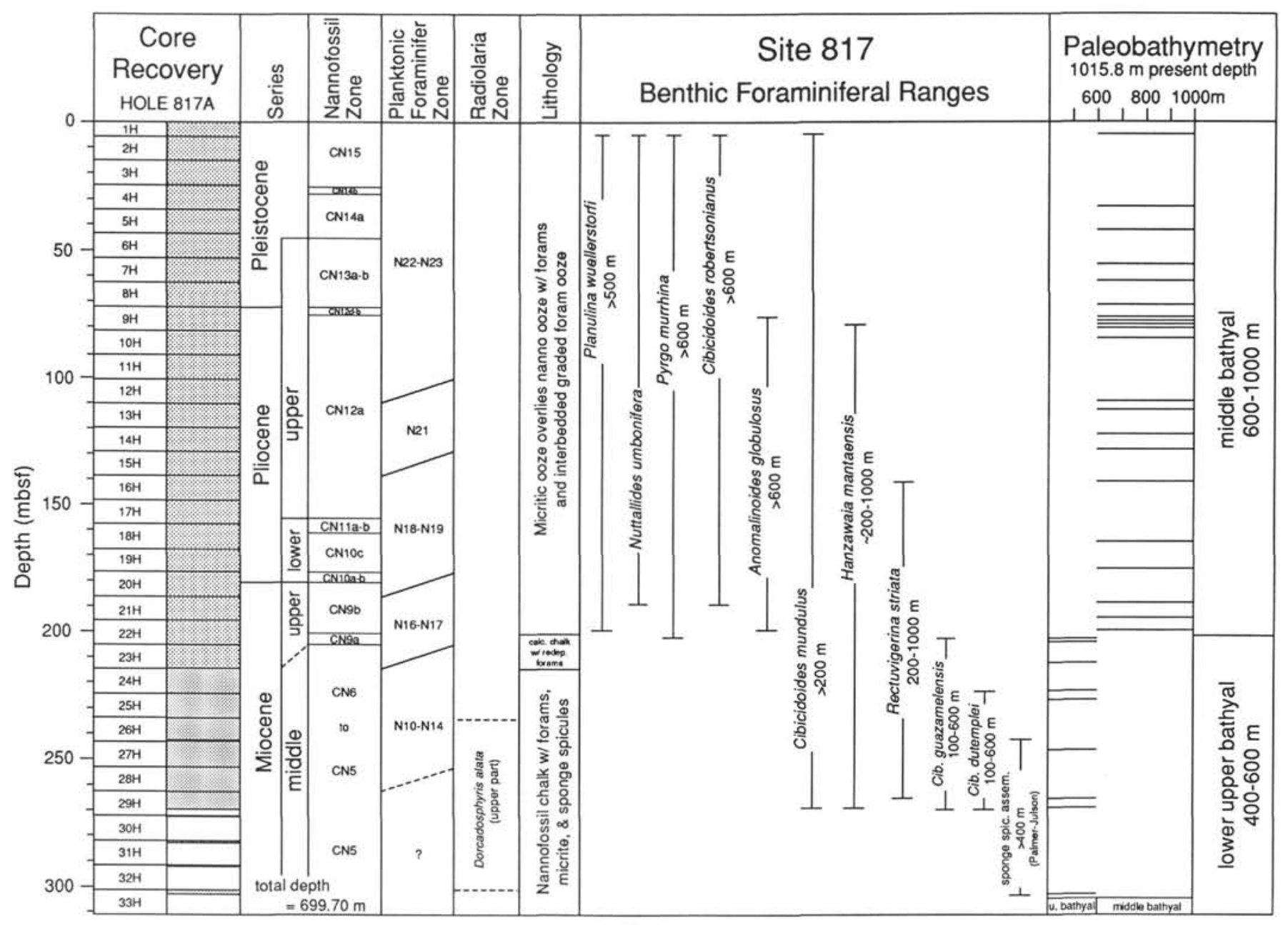

Figure 10. Site 817 benthic foraminiferal range data and paleobathymetric interpretation. Sponge spicule assemblage paleobathymetric estimate is after Davies, McKenzie, Palmer-Julson, et al. (1991). See Figure 4 caption for complete explanation. 


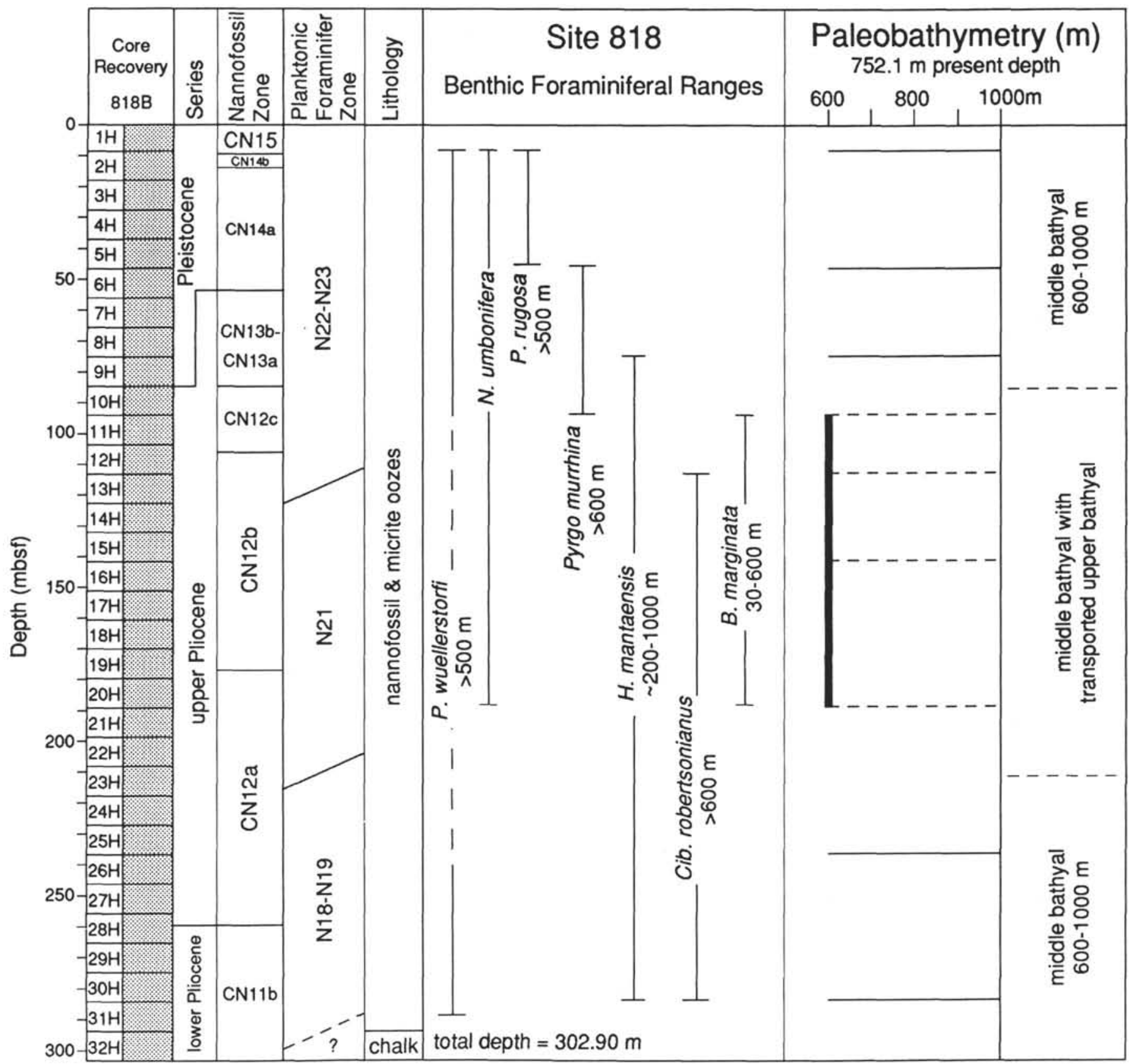

Figure 11. Site 818 benthic foraminiferal range data and paleobathymetric interpretation. The dashed lines with the solid vertical line indicate the section of increased downslope transport. See Figure 4 caption for complete explanation. 


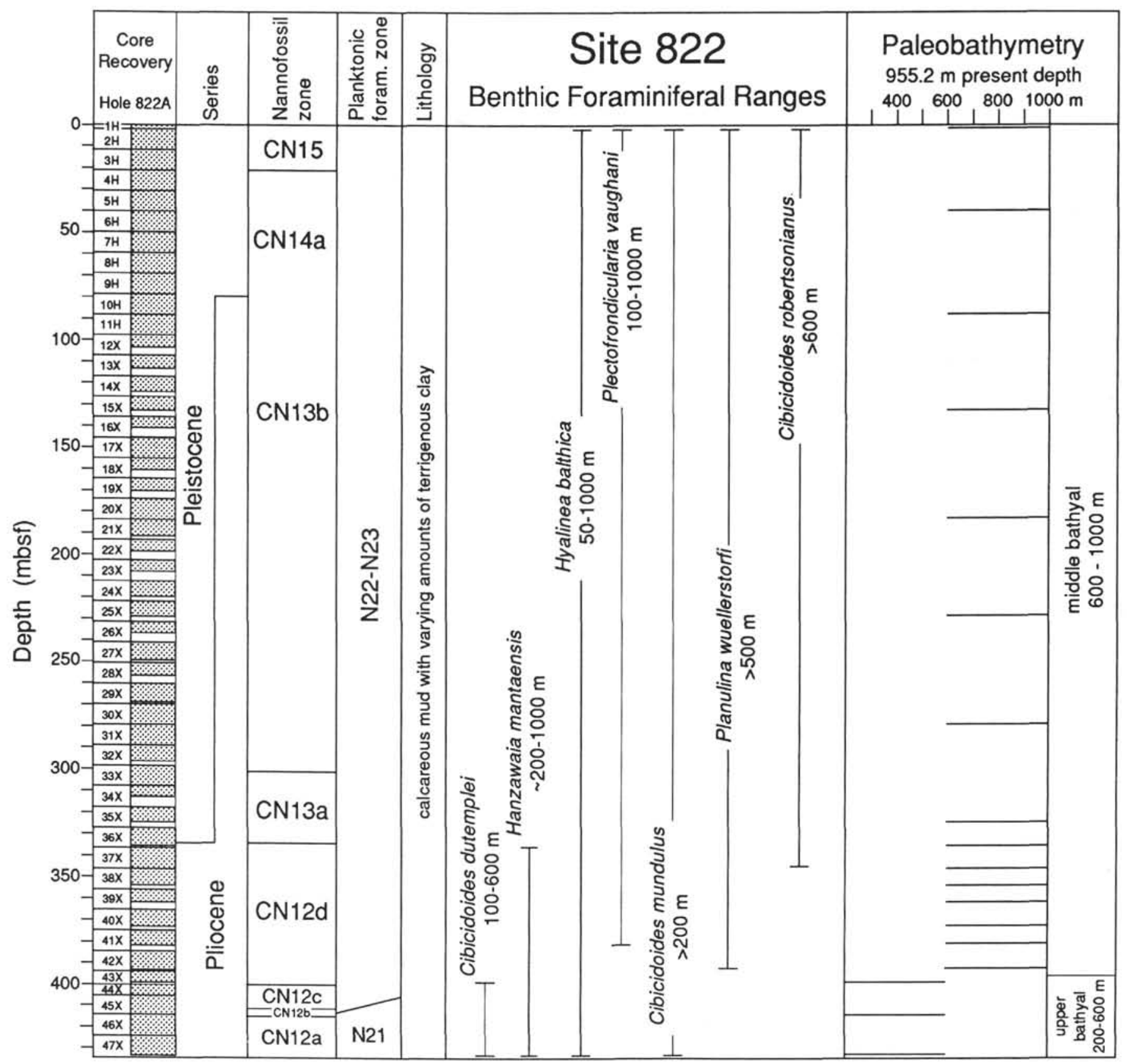

Figure 12. Site 822 benthic foraminiferal range data and paleobathymetric interpretation. See Figure 4 caption for complete explanation. 


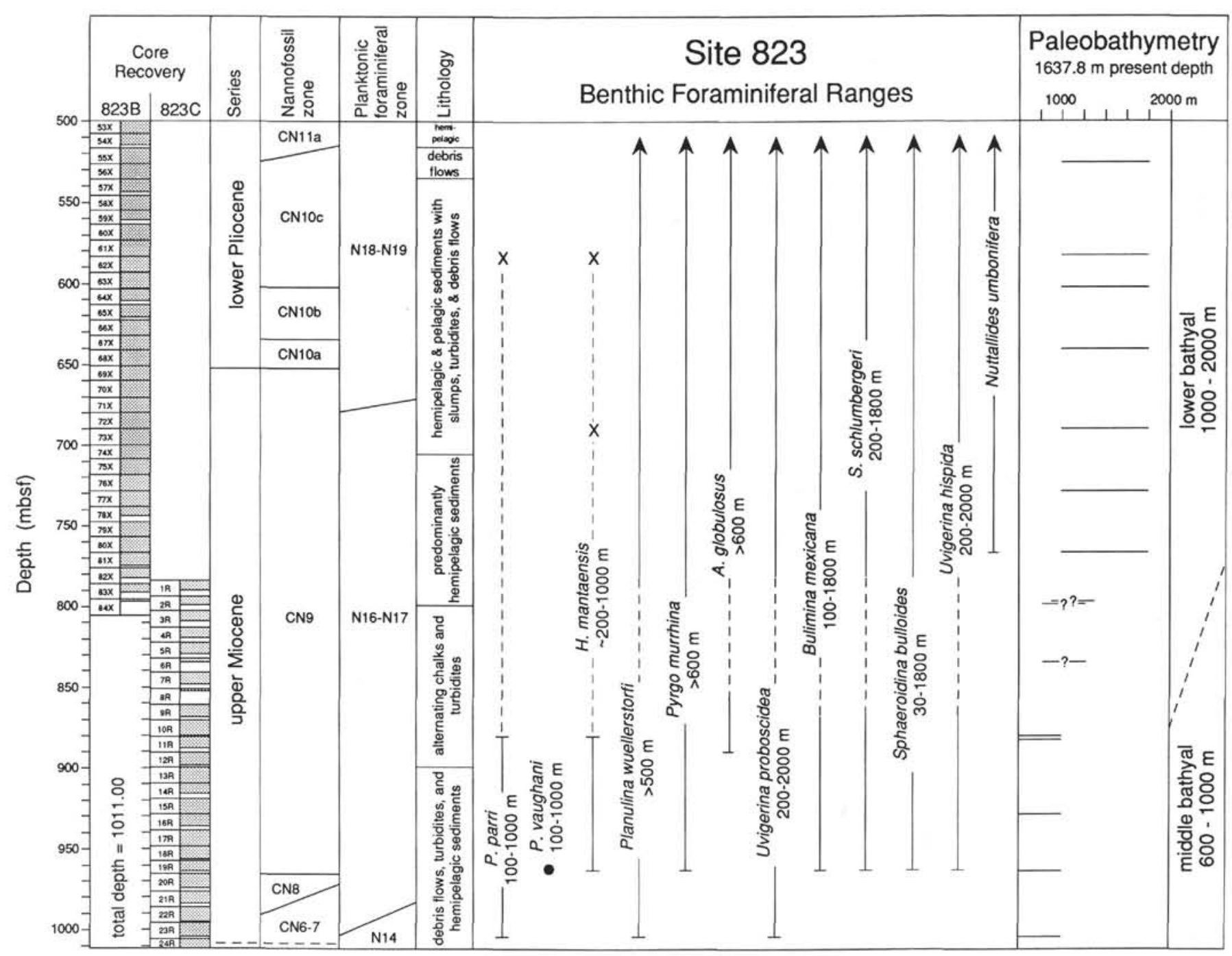

Figure 13. Site 823 benthic foraminiferal range data and paleobathymetric interpretation. Arrows indicate that these taxa range to the top of the section. X's represent single occurrences; dashed lines indicate disjunct ranges that probably reflect downslope transport. The solid circle represents a species occurrence in a single sample. See Figure 4 caption for complete explanation. 

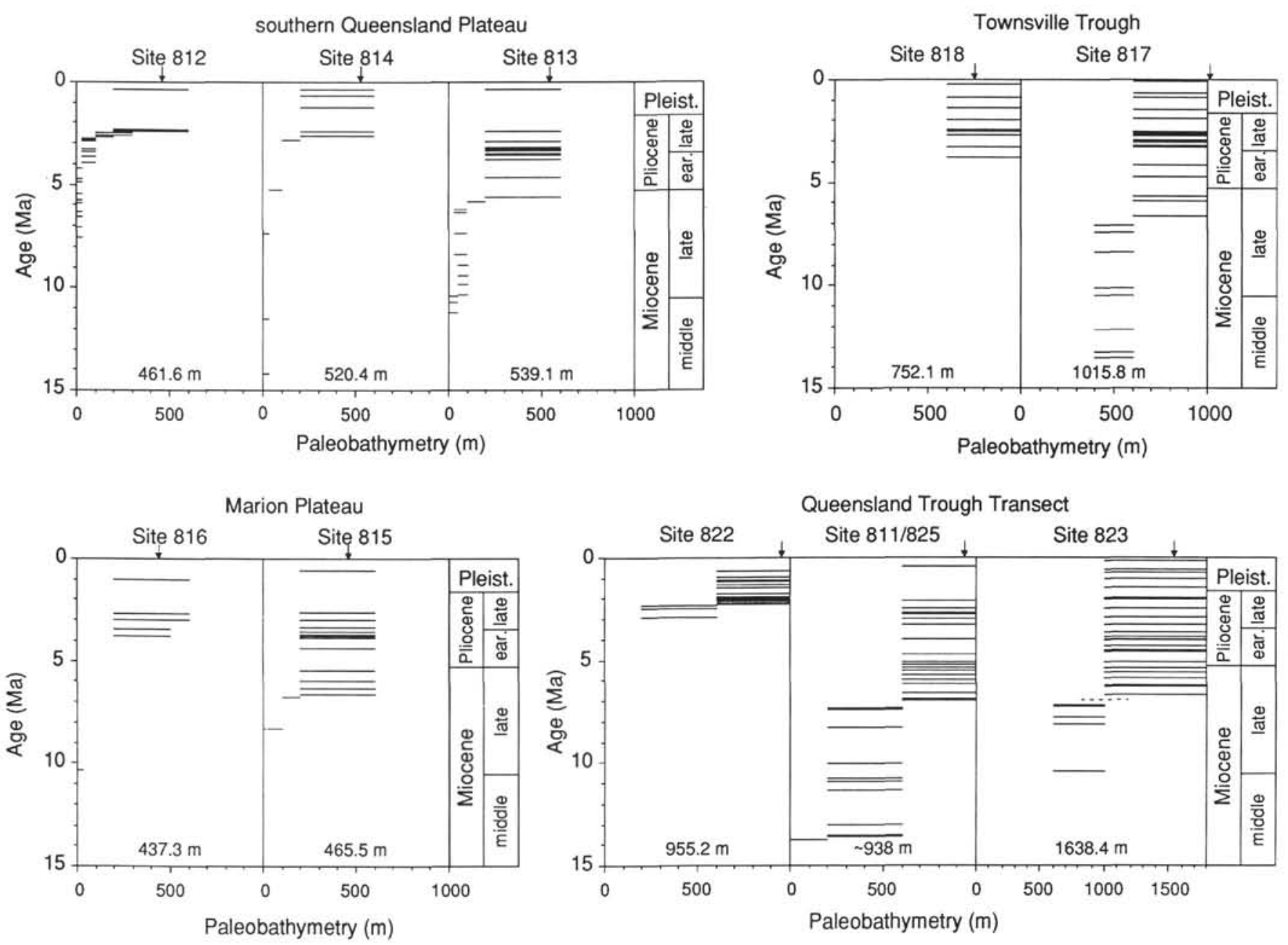

Figure 14. Paleobathymetric histories of the Leg 133 sites. Paleobathymetry is plotted vs. age. Each group is plotted beginning with the shallowest site on the left with the present depths at the bottom of each site. Note that the range of the horizontal scale for Site 823 is different from the others. 